\title{
Lithium and Sr isotopic composition of salar deposits in the Central Andes across space and time: the Salar de Pozuelos, Argentina
}

\author{
Anette Meixner $^{1} \cdot$ Ricardo N. Alonso $^{2} \cdot$ Friedrich Lucassen $^{1} \cdot$ Laura Korte $^{1} \cdot$ Simone A. Kasemann ${ }^{1}$ (i)
}

Received: 18 November 2020 / Accepted: 1 June 2021 / Published online: 7 July 2021

(c) The Author(s) 2021

\begin{abstract}
The Central Andes of South America host the largest known lithium resources in a confined area, but the primary lithium sources of the salar deposits and the mobilisation process of lithium are still a matter of speculation. Chemical weathering at or near the surface and leaching in hydrothermal systems of the active magmatic arc are considered the two main mechanisms of Li extraction from the source rock. The lithium and strontium isotope composition of typical salar deposits offer insights into the processes on how Li brine deposits in Andean evaporites are formed. Data from the Salar de Pozuelos indicate near-surface chemical weathering in a cold and dry climate as the dominant mobilisation process of Li, with evaporation being responsible for the enrichment. The Cenozoic ignimbrites are the favoured source rock for the Li, with subordinate additions from the Palaeozoic basement. The identification of the source rocks is supported by radiogenic $\mathrm{Nd}$ and $\mathrm{Pb}$ and stable B isotope data from salar deposits. A comparison with other Li brine and salt deposits in the Altiplano-Puna Plateau and its western foothills places the Salar de Pozuelos as an endmember of Li solubilisation by chemical weathering with only minor hydrothermal mobilisation of $\mathrm{Li}$.
\end{abstract}

Keywords Central Andes $\cdot$ Salar deposits $\cdot$ Lithium isotopes $\cdot$ Lithium deposits

\section{Introduction}

The arid climate and active tectonics formed and sustain numerous Cenozoic endorheic basins on the Altiplano-Puna Plateau of the Central Andes in NW Argentina, in southern Bolivia, and in the western slope of the Plateau in northern Chile between 20 and $27^{\circ} \mathrm{S}$ (e.g. Hartley and Chong 2002; Strecker et al. 2007; Quade et al. 2015). An endorheic basin containing a salt lake or a salt pan is called salar in the Andes. The continental sedimentary successions host commonly variably thick evaporite deposits dominated by halite, widespread occurrence of gypsum, and travertine deposits

Editorial handling: B. Lehmann

Simone A. Kasemann

kasemann@uni-bremen.de

1 MARUM - Center for Marine Environmental Sciences and Faculty of Geosciences, University of Bremen, Leobener Str. 8, 28359 Bremen, Germany

2 Facultad de Ciencias Naturales, Universidad Nacional de Salta and Conicet (Cega-Insugeo), Avda. Bolivia 5550, 4400 Salta, Argentina at active or fossil hydrothermal springs (e.g. Stoertz and Ericksen 1974; Alonso et al. 1991; Vandervoort et al. 1995; Risacher and Fritz 2009). The formation of the principal minerals from solutes and the hydro-chemical systematics of evaporite deposits are well understood. Lithium (Li) and boron (B) in brine and borate minerals are of economic interest, but play no or no major role in the formation of the thick evaporite deposits (e.g. seminal work summarised in Hardie and Eugster 1970; Eugster 1980; Warren 2010).

Some of the Andean salars host economic enrichments of boron minerals (Alonso 1999) and world-class brine pool deposits of lithium, presently sourcing approximately $30 \%$ of the world's lithium production and holding more than $50 \%$ of the world's Li resources (Grosjean et al. 2012; Houston et al. 2011; Munk et al. 2016; U.S. Geological Survey 2020). The occurrence of lithium enrichment in the Central Andes is geographically confined to the 'Lithium Triangle', an informal term used by the mining industry, which refers to the area between southern Bolivia, NW Argentina and NE Chile.

Boron forms a number of borate minerals within the Andean evaporite deposits and received considerable interest of the mining industry. Its concentration, distribution 
and isotope composition was studied in a number of basins over the last decades, focussing on the formation of the borates and the source rocks from which the B was leached (e.g. Alonso 1999; Ericksen and Salas 1987; Kasemann et al. 2004). Until recently, lithium in low-temperature sedimentary environments incorporated in, e.g. brines, salts and clay minerals received only minor attention. However, the rapid increase in global demand of Li for rechargeable batteries over the last decade (e.g. Mohr et al. 2012; U.S. Geological Survey 2020) fuelled the interest in the origin of these Li deposits (e.g. Ericksen and Salas 1987; Risacher and Fritz 2009; Risacher et al. 2003; Boschetti et al. 2007; Godfrey et al. 2013; Rissmann et al. 2015; López Steinmetz 2017; Munk et al. 2018; López Steinmetz et al. 2018; Godfrey and Álvarez-Amado 2020).

The source of Li, its mobilisation, pathway and enrichment in brines of Andean deposits, remain a matter of discussion. In general, $\mathrm{Li}$ is thought to be extracted into aqueous solutions by weathering and/or leaching in shallow hydrothermal systems of the active magmatic arc from the abundant Cenozoic volcanic rocks and especially the voluminous ignimbrite rocks. The fluids from hydrothermal springs and runoff from weathering is collected in endhoreic basins, and the enrichment of Li occurs in brines during evaporation and precipitation of salt in the arid climate (e.g. Risacher and Fritz 2009; Godfrey et al. 2013; Munk et al. 2018).

Congruent dissolution and leaching of silicate rocks with no secondary mineral formation produces a solution that represents the Li isotope composition of the source material. However, processes such as secondary authigenic mineral formation during incongruent weathering and hydrothermal alteration of the source rocks and during the later transport of the aqueous solution lead to isotope fractionation by preferred uptake of ${ }^{6} \mathrm{Li}$ in the structure of the residual solid (preferentially clay minerals) and enrichment of ${ }^{7} \mathrm{Li}$ in the aqueous solution (e.g. Chan et al. 1992; Pistiner and Henderson 2003; Millot et al. 2010; Wimpenny et al. 2010; for recent reviews: Tomascak et al. 2016; Penniston-Dorland et al. 2017). While the extent of $\mathrm{Li}$ isotope fractionation between the aqueous solution and the source rocks is indicative of the processes involved in $\mathrm{Li}$ extraction, the radiogenic strontium $\left({ }^{87} \mathrm{Sr} /{ }^{86} \mathrm{Sr}\right)$ isotope composition of aqueous solutions reflects, in contrast, the composition of the source. Consequentially, the strontium isotope composition of evaporites, salts and brines preserves information about the dominance of the different potential source rocks in the weathering regime at the surface and in hydrothermal regimes in the uppermost crust. The $\mathrm{O}$ and $\mathrm{H}$ isotope composition of surface brines constrains their evaporation path and potential influence of progressive evaporation on the $\mathrm{Li}$ isotope composition of the brine.
To improve our understanding on how Li brine deposits in Andean evaporites are formed, we analysed the $\mathrm{Li}$ and $\mathrm{Sr}$ isotope composition of brines, salts and intercalated siliciclastic rocks from the surface and drill cores of the Salar de Pozuelos on the Puna Plateau, NW Argentina. The Salar de Pozuelos is known as a Li brine deposit and has been subject to extensive exploration since 2008, allowing access to surface and drill core sampling. The salar basin and its catchment area is well mapped (Fig. 1; ESM1 Fig. A1), and there is no known complex hydrology or permanent water supply. The catchment area is dominated by siliciclastic marine and continental sedimentary rocks of Ordovician and Palaeogene age, with only minor outcrops of volcanic rocks. This is in contrast to other studied salars in the Central Andes, such as Salar de Hombre Muerto, Salar Olaroz, Salar de Ratones and Salar Centenario (Godfrey et al. 2013; Orberger et al. 2015; Garcia et al. 2020) with widespread outcrops of Cenozoic volcanic rocks (e.g. Schnurr et al. 2006). In order to extend the existing dataset on salar deposits and springs in the Central Andes and the Li-Triangle, we also performed a survey study on $\mathrm{Li}$ and $\mathrm{Sr}$ isotopes in surface brines and salts from salars from the Li-Triangle in northern Chile and south Bolivia (ESM2 Fig. A1). The Li and Sr isotope signatures from the Salar de Pozuelos deposit are compared with the isotope signatures of potential source rocks of the region, i.e. Cenozoic volcanic rocks, Palaeozoic (Pz) metamorphic, magmatic and sedimentary basement, and their younger sedimentary equivalents in the catchment area of the Salar de Pozuelos (this work; Meixner et al. 2020) and are discussed in the frame of the new and published data from salars of the Li-Triangle (Godfrey et al. 2013, 2019; Godfrey and Álvarez-Amado 2020; Orberger et al. 2015; Munk et al. 2018; Garcia et al. 2020). We also analysed the $\mathrm{B}$ isotope composition of the surface brines in order to place the Salar de Pozuelos into the framework of salars from the Puna Plateau and their source rock contribution (Kasemann et al. 2004).

\section{Geological setting of the Salar de Pozuelos}

The (semi)arid climate and the formation of endorheic basins with evaporite deposits started around $15 \mathrm{Ma}$ in the Puna Plateau and is ongoing since then (e.g. Alonso et al. 1991; Vandervoort et al. 1995; Strecker et al. 2007; Quade et al. 2015). The vegetation is sparse, and bare rock is the dominant surface in this high altitude cold desert (precipitation < $200 \mathrm{~mm}$; Haselton et al. 2002; Garreaud et al. 2009). While physical weathering predominates, in the summer season when water is available, chemical weathering can be a major component of the weathering regime (e.g. Hall et al. 2002). The dominant near-surface rock units of the region are Cenozoic volcanic rocks, 


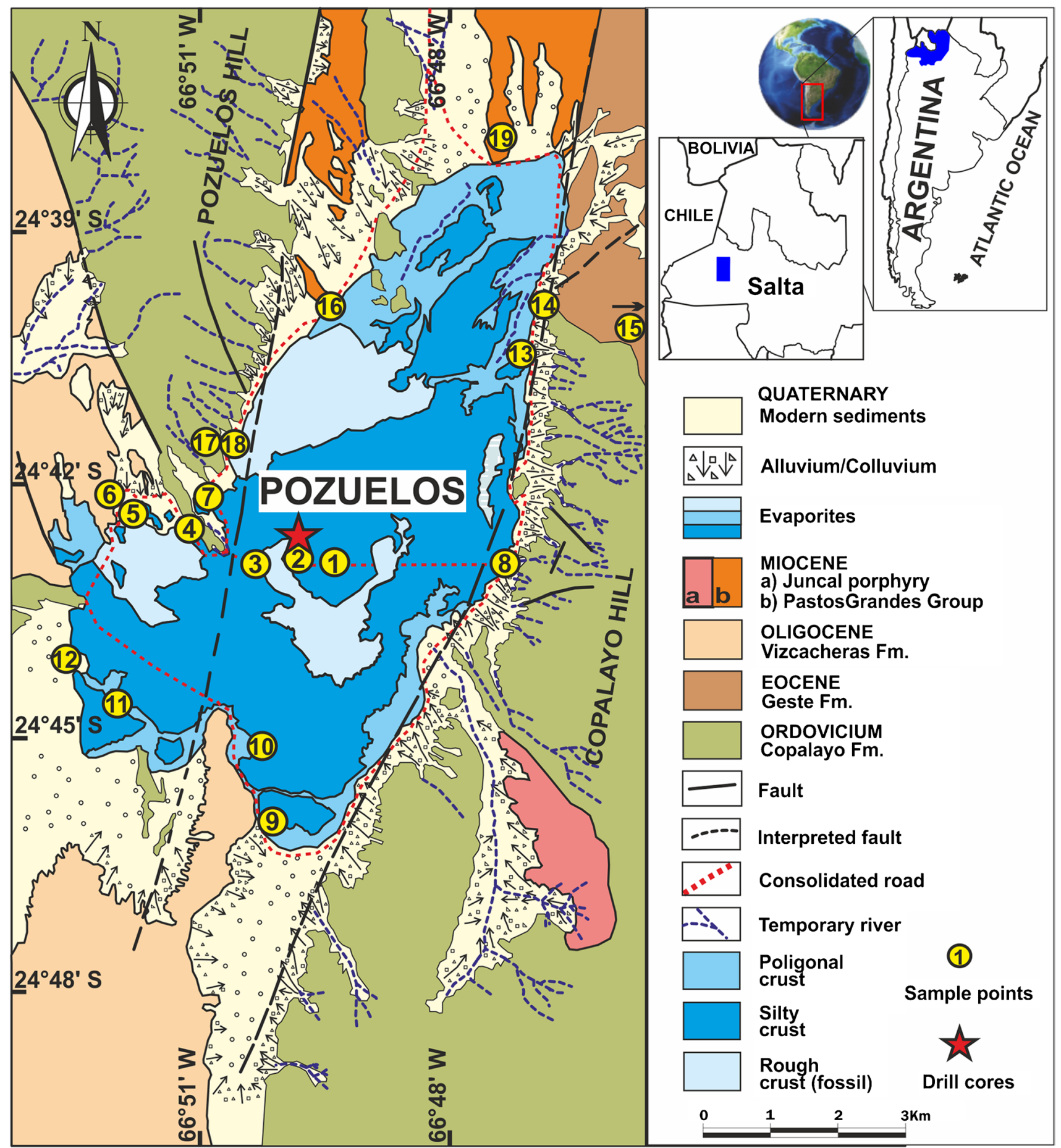

Fig. 1 Geological map of Salar de Pozuelos (modified after Martínez et al. 2020). Sample points (yellow points) refer to salar surface and catchment area samples listed in Table 1. The two drill cores L01 and
DDH1 (red star) were taken at a horizontal distance of $11 \mathrm{~m}$. For an overview of the region, see ESM2 Fig. A1

sources of siliciclastic material in these basins relate to the geology of the catchment areas, confined by the surrounding topographic highs. Input of potential air-fall from the active Cenozoic magmatic arc can also originate from outside the catchment areas. mainly andesite lavas from stratovolcanoes and monogenetic eruption centres and felsic, large-volume ignimbrites, Palaeozoic $(\mathrm{Pz})$ metamorphic, magmatic and sedimentary basement and their younger sedimentary equivalents (e.g. Reutter and Munier 2006; Schnurr et al. 2006). The main 
The salars in the Puna Plateau are classified as mature halite and/or immature clastic salars. A decreasing clastic sedimentation and finer grain sizes towards the centre of the salar, followed by a thick evaporite sequence in the sedimentary column is a characteristic of a mature salar. Alternating sequences of fine-grained sediments and evaporitic beds are typical for immature salars (Houston et al. 2011; Vinante and Alonso 2006).

\section{Lithology of the catchment area}

The Salar de Pozuelos is located in the Puna region of northwest Argentina, in the western Salta province, approximately $230 \mathrm{~km}$ west of the city of Salta and $150 \mathrm{~km}$ east of the Chilean border. The Salar de Pozuelos basin has a reported salar surface area of $82 \mathrm{~km}^{2}$ with the salt flat at approx. $3800 \mathrm{~m}$ elevation and a catchment area of $350 \mathrm{~km}^{2}$ (most recent estimates: Hains Engineering Company Limited 2018, investor report). The drainage network of the Salar de Pozuelos basin includes no permanent tributaries, but major surface water flows are expected from the southern and northern sub-basins during pluvial events that accumulated recent fluvial deposits (Fig. 1; ESM1 Fig. A1). The description of the catchment's lithology follows the geological map and accompanying explanations (Fig. 1; Blasco et al. 1996; Martínez et al. 2018,2020). The catchment area is dominated by (1) siliciclastic Ordovician marine sedimentary rocks (Copalayo Formation) that comprise shales, silt- and sandstones with no or very low-grade metamorphic overprint, and (2) much younger continental sedimentary rocks (mostly red beds of sand, silt and clays) of Eocene (Geste Fm.) and Oligocene (Vizcacheras Fm.) age that were deposited in local fluvial systems and comprise local debris and detritus and intercalated volcanic rocks (tuff layers; Blasco et al. 1996). The Miocene Pozuelos Formation also includes evaporites that formed in a playa depositional environment of an endorheic basin and (3) Quaternary sediments reflect local rock variability (Blasco et al. 1996) and are deposited as alluvial and colluvial fans in the catchment area, and-with shallower morphological gradient-as sheet sands and playa silts and clays at the margin of the salar basin (Martínez et al. 2018). Subordinate Miocene igneous rocks (composed of ignimbrites and volcanic tuffs) occur in the south of the catchment area of the Salar de Pozuelos as isolated intrusions and in the north as intercalations in Miocene sedimentary rocks (Blasco et al. 1996). Apart from the presence of volcanic ash layers in the young sediments, other volcanic detritus, produced by aeolian erosion, transport and deposition can be assumed from the persistent volcanic activity and distribution of ignimbrite in the wider surroundings (e.g. Trumbull et al. 1999; Schnurr et al. 2007; Kay et al. 2010; Brandmeier and Wörner 2016; Wörner et al. 2018), but there is no volcanic edifice in the catchment area. The sedimentary and volcanic cover is underlain by metamorphic, magmatic and sedimentary rocks of the Early Palaeozoic basement that reworked Proterozoic rocks, sourced Palaeozoic sedimentary rocks and magmas, and is the principal crustal component in Cenozoic magmatic rocks of the Andean continental arc (e.g. Trumbull et al. 1999; Lucassen et al. 2001; Kay et al. 2010).

\section{The salar basin deposits}

Salar de Pozuelos is classified as a mature salar with some immature (clastic) characteristics in the northeast of the salar. The surface of the salar is characterised by different types of salt crusts (Fig. 1; ESM1 Fig. A2; Martínez et al. 2020) that developed in different areas depending on the influence of surface runoff from the surrounding catchment area. A hard and rough salt crust is predominant and covers most of the central part of the salar that is distant from surface runoff. A smooth salt crust is developed at the margin comprising patches of a hard salt crust with polygons and a substantial amount of siliciclastic silt and clay component indicating temporary flooding by surface water (Igarzábal 1991; Martínez et al. 2018). Borates (as ulexite) are interbedded as thin beds in the upper two meters of clastic sediments in the north-eastern and western sector of the Salar de Pozuelos basin with immature (clastic) characteristics (e.g. Alonso 1999).

Hot spring activity has ceased in the Salar de Pozuelos, but a travertine field of former Pleistocene hot springs $(<100 \mathrm{ka})$ can be found along the faulted contact between the Ordovician and Paleogene rocks in the northeast sector (Martínez et al. 2018). Currently, only minor spring activity $\left({ }^{<} 20^{\circ} \mathrm{C}\right.$ ) is present at the border of the salar basin (Hains Engineering Company Limited 2018).

The basin infill of the Salar de Pozuelos is known from prospection drill holes. A detailed facies description for the salt pan evaporites and saline mudflat sediments down to ca $183 \mathrm{~m}$ depth in the centre of the salar is provided by Martínez et al. (2018) for the cores L01 and DDH1 that we used in this study. It starts from the surface with approximately $95 \mathrm{~m}$ of halite comprising scarce siliciclastic components. The halite is coarse crystalline and highly fractured at the top and trends into more competent to massive halite at the lower part. The basal unit is essentially a mixed red clay (clay to fine sandstone) and halite (subordinate) zone that has been traced in a diamond drill hole to $183 \mathrm{~m}$ depth (Martínez et al. 2018) and continues to the bottoms of the deepest drill holes at ca 320 to $383 \mathrm{~m}$ without reaching the Ordovician sedimentary rocks. Lithium enriched brines are found within the halite matrix and are expected to be present 
down to the base of the salar (Hains Engineering Company Limited 2018; LSC Lithium Cooperation 2019).

\section{Survey sampling in the Li-Triangle between 18 to $26^{\circ} \mathrm{S}$ (NW Argentina, southern Bolivia, northern Chile)}

Additional samples of natural brines and spring water from a variety of salars mainly in northern Chile, but also from Salar Uyuni, southern Bolivia and Salar de Antofalla, NW Argentina were collected (for locations, see ESM2 Fig. A1). This was done to broaden the existing database on $\mathrm{Li}$ and $\mathrm{Sr}$ isotope composition from published detailed studies on single salar systems. All sample locations are within the active magmatic arc with catchment areas that are strongly influenced by the volcanism. Only the Salar de Atacama basin is off the arc and located at the base of the western slope of the Puna Plateau, but it also collects mainly the runoff of the latter, i.e. arc material with extensive ignimbrites of Neogene age (Ramírez and Gardeweg 1982; Reutter et al. 1994).

\section{Materials and methods}

\section{Surface samples from the Salar de Pozuelos and the catchment area}

A total of 19 locations of surface outcrops were sampled in February 2011 (Table 1). Brine or water samples $(n=13)$ were taken from natural ponds or mechanically dug exploration test pits around the margin and the centre of the salar. Sampling of brines around the salar near the border between the evaporite and outcropping rocks aims at recognising potential compositional variations in the brines related to the influx from local and variable sources (for sample points (sp), refer to Fig. 1 and Table 1; regional overview, ESM2 Fig. A1). In brine ponds close to the southern border ( $n=1$, sample point sp 10) and from the centre ( $n=2$, sp 1 and 3$)$, coexisting brine and salt precipitates were collected in order to constrain potential fractionation of Li during evaporation and salt precipitation. Additional samples of salt $(n=2$, sp 2) were collected from evaporated brine in an artificial pool at the centre of the salar basin. Two borate (ulexite) samples (sp 13 and 18), were sampled from the eastern and western border of the salar, respectively. Unconsolidated siliciclastic sediments were collected from the natural ponds or exploration test pits $(n=7, \mathrm{sp} 4,5,7$ to $9,11,13,16$ and 18). Furthermore, we sampled fluid from an active spring (sp 14) at the salar's north-eastern border located within the faulted contact between the Ordovician and Paleogene rocks. The outflow of the spring is presently low, but past higher activity formed a travertine field since the Pleistocene. The travertine (sample point sp 14; sample SP-11-24) was split into 8 subsamples according to the discernible layering to test for compositional changes with time of deposition. Photographs of various sample locations are provided in the supplement (ESM1 Figs. A2 and A3). Salts (halite), brines and sediments were stored in acid-cleaned PE bottles. Silicate rocks from the catchment area of Pozuelos comprise Oligocene (sp 6) and Eocene (sp 15) sedimentary rocks, one Cenozoic ignimbrite (sp 19) and one Ordovician sedimentary rock (sp 17). The latter two samples were already analysed (Meixner et al. 2020). One unconsolidated siliciclastic sediment (sp 12) was collected from a dry riverbed close to Oligocene and Ordovician outcrops.

\section{Drill cores}

Sampling of two adjacent (11 m distance) commercial drill cores (mining company Ekeko S.A. and Lithea Inc. in 2015) in the centre of the salar (Fig. 1) aims at compositional variations in time. All salt (halite, $n=11$ ) samples have been selected from core L01 (SPZ RC001 in the company repository) in approximately 5 to $15 \mathrm{~m}$ steps down to $95.5 \mathrm{~m}$. Core DDH1 (SPZ DDH001 in the company repository) has a lower recovery in the halite zone, but comprises in its lower section from $95 \mathrm{~m}$ down to $183.5 \mathrm{~m}$ a siliciclastic sedimentary sequence with an evaporite (salt) component. Mixed evaporite-siliciclastic samples $(n=6)$ were retrieved from DDH1 in approximately 10- to 20-m steps and further separated into three fractions: clay rich, sand rich and water soluble. The respective position of the samples in the cores below surface is given in Table 1. Surface sediment (sample SP-11-07) sampled as salt clay from the centre (sp 3) was also analysed and is treated together with the core.

\section{Samples from the lithium Triangle}

Additional thermal water, brine and salt samples were collected from thermal springs, salars and lagoons/brine pools in the Lithium Triangle (ESM2 Fig. A1). Sampling includes in northern Chile the Salar Grande, Salar de las Parinas, Salar de la Isla, Salar de Pedernales, Salar de Atacama and Salar de Piedra Parada, the Lagunas de Huasco and Chaxa, and thermal springs from Quebrada Chaco del Norte, Quebrada del Rio Negro and Terma Chiriguaya. Furthermore, two salt samples were collected from the southern end of the Salar de Antofalla and from a salt pond in an ignimbrite field at Campo Negro, both from NW Argentina. Two samples are from the northern and eastern part of the Salar de Uyuni in southern Bolivia. 
Table 1 Catchment, drill core and surface samples from Salar de Pozuelos

\begin{tabular}{|c|c|c|c|c|c|c|c|}
\hline \multirow[t]{2}{*}{ Sample point } & \multirow[t]{2}{*}{ Coordinates } & \multirow[t]{2}{*}{ Brine/water } & \multicolumn{2}{|c|}{ Sample type } & \multirow[t]{2}{*}{ Travertine } & \multirow[t]{2}{*}{ Catchment } & \multirow[t]{2}{*}{ Description } \\
\hline & & & Salt & Siliciclastic & & & \\
\hline 1 & $\begin{array}{l}24^{\circ} 43^{\prime} 02.1^{\prime \prime} \mathrm{S} \\
66^{\circ} 49^{\prime} 30.7^{\prime \prime} \mathrm{W}\end{array}$ & SP-11-01 & SP-11-02 & & & & $\begin{array}{l}\text { Centre of salar brine and salt sample from } \\
\text { the same pond }\end{array}$ \\
\hline 2 & $\begin{array}{l}24^{\circ} 43^{\prime} 00.4^{\prime \prime} \mathrm{S} \\
66^{\circ} 49^{\prime} 49.1^{\prime \prime} \mathrm{W}\end{array}$ & & $\begin{array}{l}\text { SP-11-03 } \\
\text { SP-11-04 }\end{array}$ & & & & $\begin{array}{l}\text { Evaporated brines in artificial pool, with } \\
\text { pure salt remaining. } 03 \text { - cubic, } 04 \text {-flake/ } \\
\text { dendritic crystal structure }\end{array}$ \\
\hline 3 & $\begin{array}{l}24^{\circ} 43^{\prime} 00.8^{\prime \prime} \mathrm{S} \\
66^{\circ} 50^{\prime} 25.0^{\prime \prime} \mathrm{W}\end{array}$ & SP-11-05 & SP-11-06 & SP-11-07 & & & $\begin{array}{l}\text { Brine, salt and clay sample from the same } \\
\text { pond }\end{array}$ \\
\hline 4 & $\begin{array}{l}24^{\circ} 42^{\prime} 28.1^{\prime \prime} \mathrm{S} \\
66^{\circ} 51^{\prime} 17.4^{\prime \prime} \mathrm{W}\end{array}$ & SP-11-08 & & & & & $\begin{array}{l}\text { Western part of salar, brine sample from a } \\
\text { pond with minor salt }\end{array}$ \\
\hline 5 & $\begin{array}{l}24^{\circ} 42^{\prime} 11.8^{\prime \prime} \mathrm{S} \\
66^{\circ} 51^{\prime} 53.0^{\prime \prime} \mathrm{W}\end{array}$ & SP-11-10 & & & & & Western part of salar \\
\hline 6 & $\begin{array}{l}24^{\circ} 42^{\prime} 00.3^{\prime \prime} \mathrm{S} \\
66^{\circ} 52^{\prime} 08.1^{\prime \prime} \mathrm{W}\end{array}$ & & & & & $\begin{array}{l}\text { SP-11-11-A } \\
\text { SP-11-11-B } \\
\text { SP-11-11-C }\end{array}$ & $\begin{array}{l}\text { Oligocene sediment samples; mica rich red } \\
\text { sandstones }\end{array}$ \\
\hline 7 & $\begin{array}{l}24^{\circ} 42^{\prime} 12.2^{\prime \prime} \mathrm{S} \\
66^{\circ} 50^{\prime} 59.4^{\prime \prime} \mathrm{W}\end{array}$ & SP-11-12 & & & & & $\begin{array}{l}\text { Western part of salar, brine sample and } \\
\text { mixture of organics, borates and clay from } \\
\text { a test pit }\end{array}$ \\
\hline 8 & $\begin{array}{l}24^{\circ} 43^{\prime} 01.9^{\prime \prime} \mathrm{S} \\
66^{\circ} 47^{\prime} 08.7^{\prime \prime} \mathrm{W}\end{array}$ & SP-11-14 & & & & & $\begin{array}{l}\text { Eastern part of salar, brine sample from a } \\
\text { pure clay pond }\end{array}$ \\
\hline 9 & $\begin{array}{l}24^{\circ} 45^{\prime} 58.9^{\prime \prime} \mathrm{S} \\
66^{\circ} 50^{\prime} 26.7^{\prime \prime} \mathrm{W}\end{array}$ & SP-11-15 & & & & & Southern part of salar \\
\hline 10 & $\begin{array}{l}24^{\circ} 45^{\prime} 11.0^{\prime \prime} \mathrm{S} \\
66^{\circ} 50^{\prime} 42.9^{\prime \prime} \mathrm{W}\end{array}$ & SP-11-16 & SP-11-17 & & & & $\begin{array}{l}\text { Southern part of salar, brine and salt sample } \\
\text { from the same pond }\end{array}$ \\
\hline 11 & $\begin{array}{l}24^{\circ} 44^{\prime} 38.7^{\prime \prime} \mathrm{S} \\
66^{\circ} 52^{\prime} 11.2^{\prime \prime} \mathrm{W}\end{array}$ & SP-11-18 & & $\begin{array}{l}\text { SP-11-19 } \\
\text { SP-11-20 }\end{array}$ & & & $\begin{array}{l}\text { Southern part of salar, brine and sediment } \\
\text { sample from the same pond }\end{array}$ \\
\hline 12 & $\begin{array}{l}24^{\circ} 43^{\prime} 49.2^{\prime \prime} \mathrm{S} \\
66^{\circ} 52^{\prime} 47.2^{\prime \prime} \mathrm{W}\end{array}$ & & & & & & $\begin{array}{l}\text { Western part of salar, sediment sample from } \\
\text { a dry river bed }\end{array}$ \\
\hline 13 & $\begin{array}{l}24^{\circ} 40^{\prime} 49.5^{\prime \prime} \mathrm{S} \\
66^{\circ} 46^{\prime} 45.6^{\prime \prime} \mathrm{W}\end{array}$ & SP-11-21 & SP-11-22* & & & & $\begin{array}{l}\text { North-Eastern part of salar, brine sample, no } \\
\text { associated salt but ulexite* }\end{array}$ \\
\hline 14 & $\begin{array}{l}24^{\circ} 40^{\prime} 15.7^{\prime \prime} \mathrm{S} \\
66^{\circ} 46^{\prime} 33.4^{\prime \prime} \mathrm{W}\end{array}$ & SP-11-23 & & & SP-11-24 & & $\begin{array}{l}\text { North-Eastern part of salar, water sample } \\
\text { from a former hydrothermal spring and } \\
\text { associated travertine }\end{array}$ \\
\hline 15 & $\begin{array}{l}24^{\circ} 40^{\prime} 34.2^{\prime \prime} \mathrm{S} \\
66^{\circ} 44^{\prime} 50.3^{\prime \prime} \mathrm{W}\end{array}$ & & & & & SP-11-25 & Eocene sandstone \\
\hline 16 & $\begin{array}{l}24^{\circ} 40^{\prime} 09.5^{\prime \prime} \mathrm{S} \\
66^{\circ} 49^{\prime} 13.2^{\prime \prime} \mathrm{W}\end{array}$ & SP-11-27 & & SP-11-28 & & & $\begin{array}{l}\text { Western part of salar, brine samples with no } \\
\text { associated salt, sediments are sulfur rich }\end{array}$ \\
\hline 17 & $\begin{array}{l}24^{\circ} 41^{\prime} 19.6^{\prime \prime S} \mathrm{~S} \\
66^{\circ} 50^{\prime} 29.7^{\prime \prime} \mathrm{W}\end{array}$ & & & & & SP-11-29 & Ordovician sedimentary rock \\
\hline 18 & $\begin{array}{l}24^{\circ} 41^{\prime} 23.4^{\prime \prime} \mathrm{S} \\
66^{\circ} 50^{\prime} 23.8^{\prime \prime} \mathrm{W}\end{array}$ & SP-11-30 & SP11-32* & $\begin{array}{l}\text { SP-11-31-A } \\
\text { SP-11-31-B }\end{array}$ & & & $\begin{array}{l}\text { Western part of salar, brine samples with no } \\
\text { associated salt but ulexite*, sediments are } \\
\text { organic rich }\end{array}$ \\
\hline 19 & $\begin{array}{l}24^{\circ} 37^{\prime} 50.2^{\prime \prime} \mathrm{S} \\
66^{\circ} 46^{\prime} 44.2^{\prime \prime} \mathrm{W}\end{array}$ & & & & & $\begin{array}{l}\text { SP-11-34-A } \\
\text { SP-11-34-B }\end{array}$ & $\begin{array}{l}\text { Cenozoic volcanic rock (CVZ), ignimbrite } \\
\text { A-fresh, B-altered }\end{array}$ \\
\hline 20 & $\begin{array}{l}24^{\circ} 43^{\prime} 00.5^{\prime \prime} \mathrm{S} \\
66^{\circ} 49^{\prime} 49.5^{\prime \prime} \mathrm{W}\end{array}$ & & L01 & & & & Drill core (SPZ RC001), pure salt fraction \\
\hline 21 & $\begin{array}{l}24^{\circ} 43^{\prime} 00.5^{\prime \prime} \mathrm{S} \\
66^{\circ} 49^{\prime} 49.2^{\prime \prime} \mathrm{W}\end{array}$ & & & DDH1 & & & $\begin{array}{l}\text { Drill core (SPZ DDH001), salt sand and clay } \\
\text { fraction }\end{array}$ \\
\hline
\end{tabular}

\section{Sample preparation}

All brine and thermal water samples were centrifuged and aliquoted for isotope analyses, and additionally filtered through an unreactive $0.2 \mu \mathrm{m}$ Minisart ${ }^{\circledR}$ syringe filter for concentration analyses. Salt samples $(1 \mathrm{~g})$ from the surface and the drill core (L01) were dissolved in $50 \mathrm{~mL}, 18$ $\mathrm{M} \Omega$ water and subsequently prepared in the same way as brine samples for isotope and concentration analyses. The borate samples were dissolved in $1 \mathrm{~N} \mathrm{HCl}$. The travertine 
samples were crushed, powdered, repeatedly washed in 18 $\mathrm{M} \Omega$ water and dried at $110{ }^{\circ} \mathrm{C}$, and about $100 \mathrm{mg}$ of each sub-sample were dissolved in $1 \mathrm{~N} \mathrm{HCl}$. The sample solution was centrifuged and aliquots were taken for $\mathrm{Li}, \mathrm{B}$ and $\mathrm{Sr}$ analyses. Sediment samples were disintegrated with a hammer on a steel plate. Approximately $50 \mathrm{~g}$ of clean fragments were collected, washed with $18 \mathrm{M} \Omega$ water, dried at $110{ }^{\circ} \mathrm{C}$ and powdered in an agate ball-mill. The powders were repeatedly washed in $18 \mathrm{M} \Omega$ water, dried at $110{ }^{\circ} \mathrm{C}$ and reweighed. The water-soluble fraction (leachate) was saved, dried, dissolved in $\mathrm{HCl}$ and aliquoted for $\mathrm{Li}$ and $\mathrm{Sr}$ isotope analyses. Soft sediments from the salar can contain up to $32 \%$ mass fraction of water-soluble salts. Evaporitesiliciclastic mixtures from the core (DDH1) were separated by suspending and centrifuging the sediment repeatedly in $18 \mathrm{M} \Omega$ water. The siliciclastic fraction was dried at $110^{\circ} \mathrm{C}$ and reweighed. The water-soluble mass fraction of the drill core samples ranges between 4 and 17\%. The leachate was dried, redissolved in $18 \mathrm{M} \Omega$ water and treated as the brines described above. The clastic fraction was again suspended in $18 \mathrm{M} \Omega$ water, and carefully centrifuged to separate a coarsegrained, sand-rich and a fine-grained, more clay-rich fraction (hereafter sand-rich and clay-rich). The clay-rich fraction is the upper most layer in the centrifuge tube, i.e. the bulk of the samples is the sand-rich fraction. After drying, the clay-rich and sand-rich fractions were collected and separately analysed. All washed, leached and separated silicate samples were homogenised in an agate mortar before further digestion. For $\mathrm{Li}$ and radiogenic isotopes and elemental analyses, all silicate samples were digested in a 5:1 mixture of triple distilled $\mathrm{HF}$ and double distilled $\mathrm{HNO}_{3}$ at $140{ }^{\circ} \mathrm{C}$ during at least $48 \mathrm{~h}$. The sample solution was dried at $80^{\circ} \mathrm{C}$, completely re-dissolved with $2.5 \mathrm{M} \mathrm{HNO}_{3}$, cooked for $8 \mathrm{~h}$ at $140{ }^{\circ} \mathrm{C}$ and dried at $85^{\circ} \mathrm{C}$ and finally dissolved in $0.15 \mathrm{M}$ $\mathrm{HCl}$ (Meixner et al. 2020).

\section{Major and trace element analyses}

Concentrations of cations were determined by inductively coupled plasma optical emission spectroscopy (ICP-OES) using an Agilent Technologies 700 Series ICP-OES at the University of Bremen (Sediment Geochemistry Group at MARUM). The analytical uncertainty for Li and B determination was found to be $<10 \%,<2 \%$ for $\mathrm{Ca}, \mathrm{K}, \mathrm{Mg}$ and $\mathrm{Sr}$ and $<4 \%$ for $\mathrm{Na}^{+}$(2 RSD). Apart from the Salar de Uyuni, all $\mathrm{Li}$ and $\mathrm{B}$ concentrations for fluid and salt surface samples were analysed by ICP-OES. Lithium and boron concentrations of the catchment area, drill core and travertine samples were determined during the course of isotope ratio measurements, using a ThermoScientific Neptune Plus multicollector-inductively coupled plasma-mass spectrometer (MCICP-MS) at the University of Bremen, with an uncertainty of $<6 \%$ (2RSD) based on long term analyses of reference material ZGI-TB (for lithium) and IAEA-B5 (for boron).

\section{Isotope analyses}

Analyses of hydrogen and oxygen isotopes ( $\delta \mathrm{D}$ and $\delta^{18} \mathrm{O}$ ) were carried out at the Stable Isotope Laboratory at MARUM-Centre for Marine Environmental Sciences, University of Bremen by Isotope Ratio Mass Spectrometry using a ThermoFisher Scientific TC/EA (modified after Gehre et al. 2004) coupled via a ConFlow IV to a ThermoFisher Scientific MAT253. The results are reported relative to four international standards (IAEA-OH 13-16) of the International Atomic Energy Agency with a precision of $\pm 3.0 \%$ o for $\delta \mathrm{D}$ and $\pm 2.7 \%$ ofor $\delta^{18} \mathrm{O}(1 \mathrm{sd})$.

Stable isotopes of $\mathrm{Li}$ and $\mathrm{B}$ and radiogenic isotopes of $\mathrm{Sr}, \mathrm{Nd}$ and $\mathrm{Pb}$ were analysed in the laboratories of the Isotope Geochemistry Group at MARUM-Centre for Marine Environmental Sciences, University of Bremen. Lithium in aliquots of fluid, salt and silicate rock samples was quantitatively separated from its matrix in a two-step procedure using BioRad AG $50 \mathrm{~W}$-X8 resin (details in Meixner et al. 2020). Li loss during the separation procedure can result in isotopic offsets, and therefore the tails of each separation step were analysed for Li concentrations. Li loss was less than $0.5 \%$ of the aliquot in all samples and thus without influence on the Li isotope composition. Reference materials (RM), standard material and the procedural blank were processed together with each sample series for quality control. Li concentrations of sample and $\mathrm{RM}$ solutions in $2 \% \mathrm{HNO}_{3}$ were closely adjusted to $25 \mu \mathrm{g} / \mathrm{L} \mathrm{Li}( \pm 5 \%)$. Li isotope ratios were measured in the standard-sample bracketing mode on a MC-ICP MS Neptune plus (ThermoScientific) using the stable introduction system and a high efficiency X-cone. The solvent $2 \% \mathrm{HNO}_{3}$ was measured before and after each standard or sample and the average of both analyses was used as the analytical baseline for correction of the intensities on masses ${ }^{7} \mathrm{Li}$ and ${ }^{6} \mathrm{Li}$. The baseline-corrected isotope ratios are reported in the conventional $\delta^{7} \mathrm{Li}$ notation relative to the RM NIST 8545 (LSVEC Li carbonate, Flesch et al. 1973). The Li blank-input during chemical treatment was always less than $0.1 \%$ of the sample aliquot and had no effect on the isotope composition of the sample. Processed RMs were analysed in the same batch with the samples to verify the accuracy and precision of the analytical procedure. RM NIST 8545 shows a $\delta^{7} \mathrm{Li}$ value of $-0.03 \pm 0.18 \%$ ( $\left.2 \mathrm{sd}, n=18\right)$, and internal laboratory seawater standard BSW Susu Knolls has a $\delta^{7} \mathrm{Li}$ value of $+31.0 \pm 0.5 \%$ o $(2 \mathrm{sd}, n=11)$, indicating no isotopic offsets during the whole analytical procedure. The analysed RM ZGI-GM (granite) $(-0.7 \pm 0.2 \%$; $2 \mathrm{sd}, n=3)$, ZGI-BM (basalt) $(-3.3 \pm 0.2 \% \circ ; 2 \mathrm{sd}, n=2)$, ZGI-TS (black shale) $(+4.9 \pm 0.1 \% \circ ; 2 \mathrm{sd})$ and ZGI-TB-2 (shale) $(-3.4 \pm 0.1 \%$; $2 \mathrm{sd}, n=2$ ) are in line with published values (Meixner et al. 
2020; Romer et al. 2014). RM USGS-G-3 (granite) gives a value of $+0.1 \pm 0.5 \%$ o ( $2 \mathrm{sd}, n=2)$. The external reproducibility is generally $\leq 0.5 \%$ ( $2 \mathrm{sd}$ ); the repeatability of the individual $\delta^{7} \mathrm{Li}$ values is reported as two standard deviations based on multiple mass-spectrometer analyses.

Boron was separated from the sample material using microsublimation as described in Hüpers et al. (2016). Boron isotope ratios for all samples were analysed on a MC-ICP MS using the same stable introduction setting and measurement procedure as for lithium and detailed in Hüpers et al. (2016). The analyses of sample material and RM were performed repeatedly in the standard-sample bracketing mode using unprocessed SRM NIST 951 with $100 \mu \mathrm{g} / \mathrm{L}$ boron concentration as reference standard. The isotope data were expressed in the delta notation relative to unprocessed SRM NIST 951 (standard boric acid). Accuracy and repeatability for the separation procedure and measurement was checked through NIST SRM 951 and the internal bottom seawater standard Susu Knolls. SRM NIST 951 shows $\delta^{11} B$ values of $+0.01 \pm 0.13 \%$ ( $(2 \mathrm{sd}, n=7)$, indicating no isotope fractionation during sublimation. The $\delta^{11} \mathrm{~B}$ values of seawater IAEA-B $1(+39.9 \pm 0.2 \%$; $2 \mathrm{sd}, n=5)$ and of our laboratory internal seawater standard BSW Susu Knolls (Eastern Manus basin) $(+39.8 \pm 0.5 \% \circ ; 2 \mathrm{sd}, n=5)$ overlap within uncertainty with literature values on modern seawater $(+39.61 \pm 0.2 \%$, $2 \mathrm{sd}_{\text {mean }}$, Foster et al. 2010). Boron isotope composition of groundwater RM IAEA-B3 $(-21.96 \pm 0.02 \%$; $2 \mathrm{sd}, n=1)$ falls near the published values (e.g. Gonfiantini et al. 2003 compiled (-21.33 $\pm 0.9 \%$, 1sd) and Mahlknecht et al. 2017 $(-21.2 \pm 0.4 \%$ o, $2 \mathrm{sd}))$. The repeatability of the individual $\delta^{11} \mathrm{~B}$ values is given as two standard deviations based on multiple mass-spectrometer analyses.

After general sample preparation, digestion (detailed above), and re-dissolution in $2 \mathrm{~N} \mathrm{HNO}_{3}$, chemical separation of $\mathrm{Sr}, \mathrm{Nd}$ and $\mathrm{Pb}$ followed the methods presented in Höppner et al. (2018). Total procedural blanks are $<140 \mathrm{pg}$ for $\mathrm{Sr},<80 \mathrm{pg}$ for $\mathrm{Nd}$ and $<60 \mathrm{pg}$ for $\mathrm{Pb}$. Radiogenic isotope ratios of all sample materials were analysed on a thermal ionisation mass spectrometer Triton (ThermoScientific). $\mathrm{Nd}$ and $\mathrm{Pb}$ isotope ratios were analysed in the static multicollection mode and $\mathrm{Sr}$ isotope ratios in the dynamic multicollection mode. Instrumental mass fractionation during $\mathrm{Sr}$ isotope analysis was corrected using the stable isotope ratio of ${ }^{86} \mathrm{Sr} /{ }^{88} \mathrm{Sr}(=0.1194)$. The analytical accuracy and external long-term reproducibility for ${ }^{87} \mathrm{Sr} /{ }^{86} \mathrm{Sr}$ of reference material NIST SRM 987 in this study was $0.710246 \pm 0.000011$ (2SD, $n=24$; period: May 2015 to May 2017). This is within the range of published values analysed by TIMS of $0.710250 \pm 0.000034$ ( $2 \mathrm{SD}, n=1245$, data $<0.7102$ and $>0.7103$ are discarded) calculated from GeoRem database (query September 2017; http://georem. mpch-mainz.gwdg.de). Instrumental mass fractionation during $\mathrm{Nd}$ isotope analyses was corrected to ${ }^{146} \mathrm{Nd} /{ }^{144} \mathrm{Nd}$
$(=0.7219)$. The analytical accuracy and external longterm reproducibility for ${ }^{143} \mathrm{Nd} /{ }^{144} \mathrm{Nd}$ for reference material JNdi- 1 was $0.512093 \pm 0.000009$ ( $2 \mathrm{SD}, n=27$; period: May 2015 to May 2017) and matches the published values of $0.512106 \pm 0.000027$ ( $2 \mathrm{SD}, n=211$, data $<0.51204$ and $>0.51217$ are discarded) analysed by TIMS (GeoRem database; query September 2017; http://georem.mpchmainz.gwdg.de). The $\varepsilon_{\mathrm{Nd}}$ notation is reported relative to the Chondritic Uniform Reservoir (CHUR) with a value of ${ }^{143} \mathrm{Nd} /{ }^{144} \mathrm{Nd}=0.512638$ (Wasserburg and DePaolo 1979). Instrumental mass fractionation for $\mathrm{Pb}$ isotope analysis was corrected using a factor of $1.001(0.1 \%)$ per atomic mass unit based on the repeated analyses of NIST SRM 981. The reproducibility including the correction for mass fractionation is better than $0.1 \%$ of the respective ratio, which is the assumed uncertainty on the $\mathrm{Pb}$ isotope ratios. The uncertainty of the radiogenic isotope analyses is reported as two standard deviation of the mean $\left(2 \mathrm{sd}_{\text {mean }}\right)$.

\section{Results}

All new data referred to in the results section are in the Tables listed below, in the supplement, and are also available through the World Data Center Pangaea (https://doi.org/10. 1594/PANGAEA.928849, Meixner et al. 2021). Catchment area, salar surface basin, and drill core samples from Salar de Pozuelos were analysed for $\mathrm{Li}$ and $\mathrm{Sr}$ isotope composition and Li contents (Tables 2, 3, and 4). Surface brines and salts, and salts from core L01 were also analysed for their B isotope composition and elemental contents (Tables 3 and 4), plus $\mathrm{O}$ and $\mathrm{H}$ isotopic compositions in surface brines (ESM3 Table A1). In addition, $\mathrm{Nd}$ and $\mathrm{Pb}$ isotope compositions in silicate sediment samples from the catchment area, the salar and the drill core DDH1 were analysed (ESM3 Tables A2 and A3). We also included $\mathrm{Li}, \mathrm{Sr}$ and B isotope composition and elemental contents of brine samples from salars and thermal springs in a survey study of locations within the Lithium Triangle (Table 5). For locations with solely salt samples, only the $\mathrm{Sr}$ isotope composition is available. Travertine $\mathrm{Li}, \mathrm{B}$ and $\mathrm{Sr}$ isotope composition are in ESM3 Table A4. Elemental compositions of surface brine and salt (ESM3 Table A5), salt of core L01 (ESM3 Table A6), and brines of the Li-Triangle (ESM3 Table A7) are also documented.

\section{Elemental composition of the surface brines and salts, and salts from core L01}

In the brine, sodium comprises 76 to $96 \%$ (molar; most samples $>89 \%$ ) of the analysed cations ( $\mathrm{Na}, \mathrm{K}, \mathrm{Li}, \mathrm{B}, \mathrm{Ca}, \mathrm{Mg}$, $\mathrm{Sr})$. The total load of dissolved cations as chloride ranges between 0.14 and $5.1 \mathrm{~mol} / \mathrm{l}$ (ESM1 Fig. A4). The Li contents 
Table 2 Isotope and concentration data for the catchment and the salar sediments

\begin{tabular}{|c|c|c|c|c|c|c|c|}
\hline Sample numbe & & $\delta^{7} \mathrm{Li}(\% o) 2 \mathrm{sd}$ & $\mathrm{Li}(\mu \mathrm{g} / \mathrm{g})$ & ${ }^{87} \mathrm{Sr} /{ }^{86} \mathrm{Sr} 2 \mathrm{sd}$ mean & $\delta^{7} \operatorname{Li}(\% o) 2 \mathrm{sd}$ & $\mathrm{Li}(\mathrm{mg} / \mathrm{L})$ & ${ }^{87} \mathrm{Sr} /{ }^{86} \mathrm{Sr} 2 \mathrm{sd}_{\text {mean }}$ \\
\hline Catchment & Age & Washed rocks & \multicolumn{5}{|c|}{ Water-soluble fraction } \\
\hline SP-11-11-A & Oligocene & $4.3(1)$ & 29 & $0.714014(8)$ & $14.7(2)$ & 394 & $0.710634(8)$ \\
\hline SP-11-11-B & Oligocene & $4.9(2)$ & 34 & $0.718071(7)$ & $10.0(2)$ & 1271 & $0.710555(6)$ \\
\hline SP-11-11-C & Oligocene & $9.3(4)$ & 26 & $0.71394(5)$ & $22.9(1)$ & 39 & $0.711295(7)$ \\
\hline SP-11-25 & Eocene & $12.8(1)$ & 25 & $0.717522(5)$ & $12.2(2)$ & 4.3 & $0.715592(7)$ \\
\hline SP-11-29 & Ordovician & $-1.3(2)$ & 31 & $0.73130(1)$ & $14.3(2)$ & 8.3 & $0.726735(6)$ \\
\hline SP-11-34-A & Cenozoic & $-2.5(2)$ & 24 & $0.71113(6)$ & $9.8(1)$ & 4.8 & $0.710295(6)$ \\
\hline SP-11-34-B & Cenozoic & $-4.7(1)$ & 28 & - & $12.8(1)$ & 3.1 & $0.710246(6)$ \\
\hline Sediments & & \multicolumn{3}{|l|}{ Washed sediments } & \multicolumn{3}{|c|}{ Water-soluble fraction } \\
\hline SP-11-07S & Sand-rich & $-0.1(1)$ & 63 & $0.711379(4)$ & $17.3(2)$ & 74.0 & $0.711917(4)$ \\
\hline SP-11-07C & Clay-rich & $-0.6(0)$ & 311 & $0.715641(4)$ & & & \\
\hline SP-11-19 & & $0.1(1)$ & 47 & $0.711052(8)$ & $17.1(1)$ & 86 & $0.711166(7)$ \\
\hline SP-11-20 & Dry river bed & $-0.3(1)$ & 25 & $0.711468(7)$ & $-1.9(1)$ & 1.1 & $0.710934(8)$ \\
\hline SP-11-28 & & $-3.6(2)$ & 130 & $0.713074(7)$ & $12.7(1)$ & 344 & $0.712035(8)$ \\
\hline SP-11-31a & & $0.8(1)$ & 589 & $0.715784(7)$ & $16.1(0)$ & 1280 & $0.715098(7)$ \\
\hline SP-11-31b & & $0.6(1)$ & 563 & $0.715610(7)$ & $16.5(2)$ & 835 & $0.715144(7)$ \\
\hline
\end{tabular}

Uncertainties are valid for the last digits

Table 3 Isotope and concentration data for fluid and salt surface samples

\begin{tabular}{|c|c|c|c|c|c|}
\hline Sample number & $\delta^{7} \mathrm{Li}(\% o) 2 \mathrm{sd}$ & $\mathrm{Li}(\mathrm{mg} / \mathrm{L})$ & $\delta^{11} \mathrm{~B}(\% o) 2 \mathrm{sd}$ & $\mathrm{B}(\mathrm{mg} / \mathrm{L})$ & ${ }^{87} \mathrm{Sr} /{ }^{86} \mathrm{Sr} 2 \mathrm{sd}_{\text {mean }}$ \\
\hline \multicolumn{6}{|l|}{ Brine and water } \\
\hline SP $11-01$ & $17.2(4)$ & 960 & $-19.3(1)$ & 470 & 0.712475 \\
\hline SP $11-05$ & $17.5(1)$ & 1200 & $-16.5(1)$ & 400 & $0.71191(5)$ \\
\hline SP $11-08$ & $16.8(3)$ & 220 & $-10.4(1)$ & 210 & $0.712471(4)$ \\
\hline SP $11-10$ & $18.5(3)$ & 500 & $-8.5(1)$ & 490 & 0.710801 \\
\hline SP $11-12$ & $19.3(2)$ & 390 & $-16.7(1)$ & 480 & 0.712488 \\
\hline SP $11-14$ & $16.0(3)$ & 230 & $-3.4(1)$ & 340 & $0.715212(5)$ \\
\hline SP $11-15$ & $15.4(2)$ & 19 & $-2.2(1)$ & 15 & 0.711478 \\
\hline SP $11-16$ & $16.7(1)$ & 620 & $-8.2(1)$ & 420 & 0.712171 \\
\hline SP $11-18$ & $15.9(1)$ & 180 & $-1.8(2)$ & 120 & 0.711207 (4) \\
\hline SP 11-21 & $16.0(2)$ & 33 & $-11.3(1)$ & 260 & 0.714932 \\
\hline SP 11-23 & $11.4(1)$ & 9 & $-9.1(1)$ & 28 & $0.719703(5)$ \\
\hline SP $11-23 f$ & $11.3(2)$ & & & & \\
\hline SP $11-27$ & $16.6(3)$ & 140 & $-6.4(1)$ & 120 & 0.711359 \\
\hline SP 11-30 & $16.9(2)$ & 360 & $-11.8(1)$ & 340 & 0.712932 \\
\hline \multicolumn{6}{|l|}{ Salt/Halite* } \\
\hline SP $11-02$ & $17.0(2)$ & 55 & $-19.9(1)$ & 32 & $0.712451(5)$ \\
\hline SP $11-03$ & $16.5(2)$ & 340 & $-17.3(1)$ & 170 & $0.712545(5)$ \\
\hline SP $11-03 f$ & $16.3(3)$ & & & & \\
\hline SP 11-04 & $16.9(4)$ & 1040 & $-16.9(1)$ & 540 & $0.712535(2)$ \\
\hline SP 11-04f & $17.0(2)$ & & & & \\
\hline SP 11-06 & $17.3(2)$ & 74 & $-16.5(1)$ & 31 & 0.711918 \\
\hline SP $11-17$ & $16.6(2)$ & 140 & $-8.5(1)$ & 110 & $0.7121765(5)$ \\
\hline \multicolumn{6}{|l|}{ Borates } \\
\hline SP11-22 & $8.2(1)$ & & $-17.5(1)$ & & $0.715248(5)$ \\
\hline SP11-32 & $12.4(4)$ & & $-6.7(1)$ & & $0.71543(5)$ \\
\hline
\end{tabular}




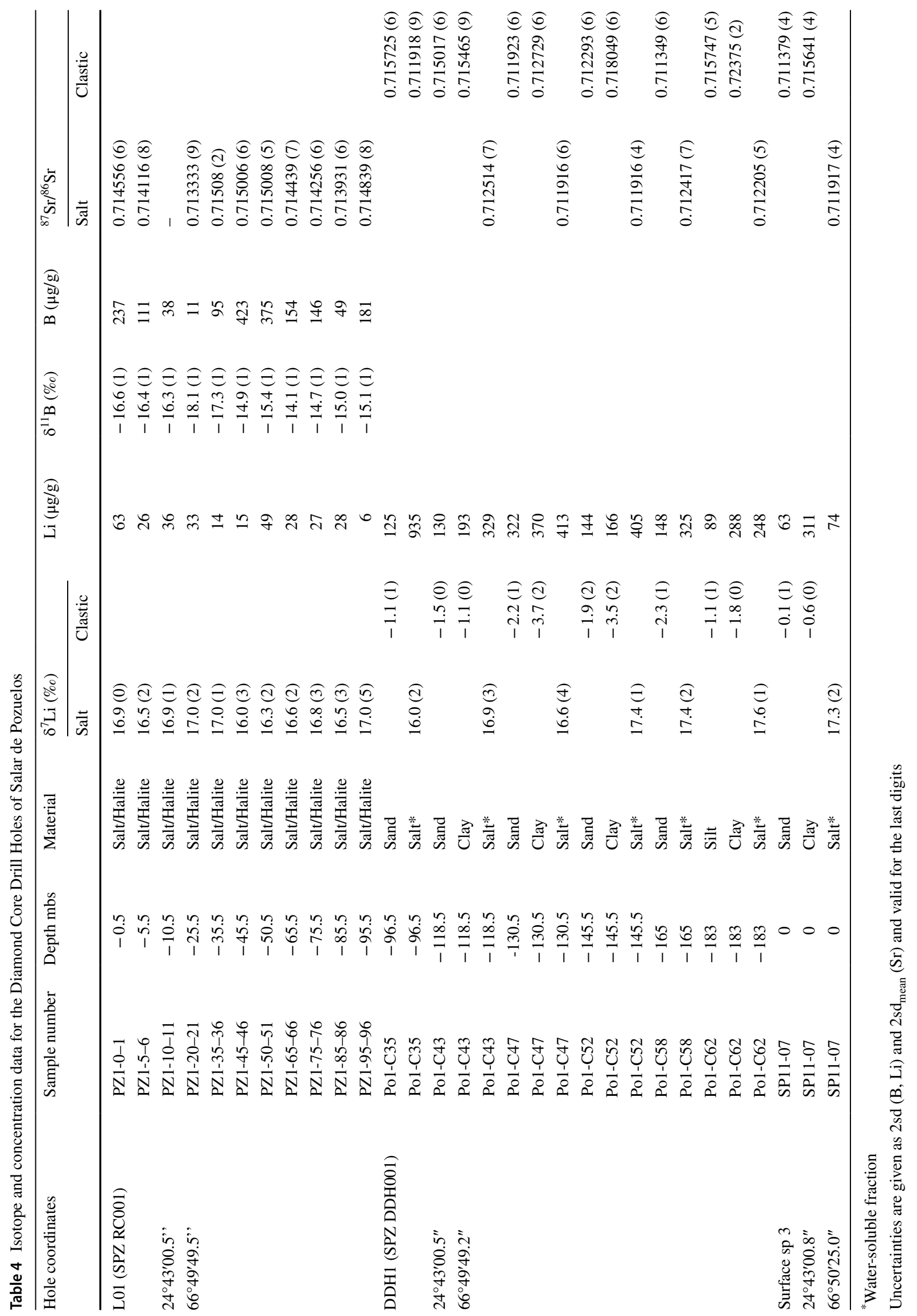


Table 5 Isotope and concentration data for samples from the Lithium Triangle

\begin{tabular}{|c|c|c|c|c|c|c|c|c|c|}
\hline Sample point & Locality & Coordinates & Brine/water & Salt & $\delta^{7} \mathrm{Li}(\% o) 2 \mathrm{sd}$ & $\mathrm{Li}(\mathrm{mg} / \mathrm{L})$ & $\delta^{11} \mathrm{~B}(\% o) 2 \mathrm{sd}$ & $\mathrm{B}(\mathrm{mg} / \mathrm{L})$ & ${ }^{87} \mathrm{Sr} /{ }^{86} \mathrm{Sr} 2 \mathrm{sd}_{\text {mean }}$ \\
\hline CA1 & Salar Grande & $\begin{array}{l}25^{\circ} 56^{\prime} 45.6^{\prime \prime} \mathrm{S} \\
68^{\circ} 42^{\prime} 24.3^{\prime \prime} \mathrm{W}\end{array}$ & $\begin{array}{l}\text { W1 } \\
\text { W2 }\end{array}$ & $\begin{array}{l}\text { S1 } \\
\text { S2 }\end{array}$ & $\begin{array}{l}6.8(1) \\
6.3(3)\end{array}$ & $\begin{array}{r}600 \\
21\end{array}$ & $\begin{array}{l}16.2(1) \\
15.6(1)\end{array}$ & $\begin{array}{r}1390 \\
50\end{array}$ & $\begin{array}{l}0.708649(6) \\
0.708502(5) \\
0.708618(6) \\
0.708657(6)\end{array}$ \\
\hline CA2 & $\begin{array}{l}\text { Salar de las } \\
\text { Parinas }\end{array}$ & $\begin{array}{l}25^{\circ} 48^{\prime} 42.0^{\prime \prime} \mathrm{S} \\
68^{\circ} 28^{\prime} 39.0^{\prime \prime} \mathrm{W}\end{array}$ & W4 & S4 & $6.2(2)$ & 453 & $0.0(1)$ & 505 & $\begin{array}{l}0.707999(6) \\
0.707981(7)\end{array}$ \\
\hline CA3 & $\begin{array}{l}\text { Salar de la Isla } \\
\text { (1) }\end{array}$ & $\begin{array}{l}25^{\circ} 40^{\prime} 15.0^{\prime \prime} \mathrm{S} \\
68^{\circ} 34^{\prime} 30.0^{\prime \prime} \mathrm{W}\end{array}$ & $\begin{array}{l}\text { W6 } \\
\text { W8 }\end{array}$ & $\begin{array}{l}\text { S6 } \\
\text { S8 }\end{array}$ & $\begin{array}{l}10.9(1) \\
11.2(2)\end{array}$ & $\begin{array}{l}70 \\
66\end{array}$ & $\begin{array}{l}-2.7(1) \\
-6.5(1)\end{array}$ & $\begin{array}{l}25.4 \\
17.3\end{array}$ & $\begin{array}{l}0.709181(6) \\
0.707435(7) \\
0.709467(8) \\
0.707564(7)\end{array}$ \\
\hline CA4 & $\begin{array}{l}\text { Salar de la Isla } \\
\text { (2) } \\
\text { Volcan 'Dos } \\
\text { Crateros' }\end{array}$ & $\begin{array}{l}25^{\circ} 39^{\prime} 10.3^{\prime \prime} \mathrm{S} \\
68^{\circ} 38^{\prime} 08.4^{\prime \prime} \mathrm{W}\end{array}$ & W9 & & $11.0(2)$ & 37 & $-3.7(1)$ & 7.8 & $0.707368(9)$ \\
\hline CA5 & $\begin{array}{l}\text { Quebrada Chaco } \\
\text { del Norte }\end{array}$ & $\begin{array}{l}25^{\circ} 25^{\prime} 59.9^{\prime \prime} \mathrm{S} \\
69^{\circ} 16^{\prime} 00.1^{\prime \prime} \mathrm{W}\end{array}$ & W11 & & $8.4(3)$ & 1.5 & $7.8(1)$ & 0.49 & $0.707936(6)$ \\
\hline CA6 & $\begin{array}{l}\text { Salar de Peder- } \\
\text { nales (1) }\end{array}$ & $\begin{array}{l}26^{\circ} 21^{\prime} 44.8^{\prime \prime} \mathrm{S} \\
69^{\circ} 11^{\prime} 22.6^{\prime \prime} \mathrm{W}\end{array}$ & W13 & & $10.7(1)$ & 50 & $16.7(1)$ & 22.6 & $0.708715(6)$ \\
\hline CA14 & $\begin{array}{l}\text { Salar de Peder- } \\
\text { nales (2) }\end{array}$ & $\begin{array}{l}26^{\circ} 16^{\prime} 07.4^{\prime \prime} \mathrm{S} \\
69^{\circ} 15^{\prime} 02.1^{\prime \prime} \mathrm{W}\end{array}$ & & S26 & & & & & $0.707181(7)$ \\
\hline CA15 & $\begin{array}{l}\text { Salar de Peder- } \\
\text { nales (3) }\end{array}$ & $\begin{array}{l}26^{\circ} 14^{\prime} 23.2^{\prime \prime} \mathrm{S} \\
69^{\circ} 15^{\prime} 23.8^{\prime \prime} \mathrm{W}\end{array}$ & & S27 & & & & & $0.707222(4)$ \\
\hline CA7 & $\begin{array}{l}\text { Quebrada del } \\
\text { Rio Negro } \\
\text { Banos Rio Negro }\end{array}$ & $\begin{array}{l}26^{\circ} 30^{\prime} 41.0^{\prime \prime} \mathrm{S} \\
68^{\circ} 49^{\prime} 10.9^{\prime \prime} \mathrm{W}\end{array}$ & $\begin{array}{l}\text { W14 } \\
\text { W16 }\end{array}$ & & $\begin{array}{l}7.3(2) \\
7.3(0)\end{array}$ & $\begin{array}{l}34 \\
28\end{array}$ & $\begin{array}{l}3.6(1) \\
4.6(1)\end{array}$ & $\begin{array}{l}24.4 \\
22.2\end{array}$ & $\begin{array}{l}0.707419(6) \\
0.707354(6)\end{array}$ \\
\hline CA8 & $\begin{array}{l}\text { Laguna de } \\
\text { Huasco }\end{array}$ & $\begin{array}{l}20^{\circ} 16^{\prime} 38.4^{\prime \prime} \mathrm{S} \\
68^{\circ} 53^{\prime} 00.0^{\prime \prime} \mathrm{W}\end{array}$ & W18 & S18 & $7.0(2)$ & 26 & $6.8(1)$ & 2.1 & $\begin{array}{l}0.706435(5) \\
0.706217(6)\end{array}$ \\
\hline CA9 & $\begin{array}{l}\text { Terma } \\
\text { Chiriguaya }\end{array}$ & $\begin{array}{l}18^{\circ} 20^{\prime} 27.6^{\prime \prime} \mathrm{S} \\
69^{\circ} 10^{\prime} 28.8^{\prime \prime} \mathrm{W}\end{array}$ & W19 & & $6.0(2)$ & 1.2 & $5.2(1)$ & 34.2 & $0.707445(6)$ \\
\hline CA10 & $\begin{array}{l}\text { Salar de Ata- } \\
\text { cama (1) } \\
\text { Laguna Chaxa }\end{array}$ & $\begin{array}{l}23^{\circ} 19^{\prime} 48.9^{\prime \prime} \mathrm{S} \\
68^{\circ} 10^{\prime} 02.4^{\prime \prime} \mathrm{W}\end{array}$ & $\begin{array}{l}\text { W20 } \\
\text { W21 }\end{array}$ & $\begin{array}{l}\text { S20 } \\
\text { S21 }\end{array}$ & $\begin{array}{l}9.7(2) \\
9.7(2)\end{array}$ & $\begin{array}{l}279 \\
371\end{array}$ & $\begin{array}{l}-8.3(1) \\
-8.0(1)\end{array}$ & $\begin{array}{l}221 \\
290\end{array}$ & $\begin{array}{l}0.709773(6) \\
0.709782(7) \\
0.709714(6) \\
0.709633(6)\end{array}$ \\
\hline CA11 & $\begin{array}{l}\text { Salar de Ata- } \\
\text { cama (2) }\end{array}$ & $\begin{array}{l}23^{\circ} 16^{\prime} 18.8^{\prime \prime} \mathrm{S} \\
68^{\circ} 10^{\prime} 37.0^{\prime \prime} \mathrm{W}\end{array}$ & & $\mathrm{S} 22$ & & & & & $0.710434(6)$ \\
\hline CA12 & $\begin{array}{l}\text { Salar de Ata- } \\
\text { cama (3) }\end{array}$ & $\begin{array}{l}23^{\circ} 33^{\prime} 58.7^{\prime \prime} \mathrm{S} \\
68^{\circ} 07^{\prime} 16.8^{\prime \prime} \mathrm{W}\end{array}$ & & $\mathrm{S} 23$ & & & & & $0.708267(6)$ \\
\hline CA13 & $\begin{array}{l}\text { Salar de Piedra } \\
\text { Parada }\end{array}$ & $\begin{array}{l}26^{\circ} 22^{\prime} 24.6^{\prime \prime} \mathrm{S} \\
68^{\circ} 43^{\prime} 48.0^{\prime \prime} \mathrm{W}\end{array}$ & & $\begin{array}{l}\text { S24 } \\
\text { S25 }\end{array}$ & & & & & $\begin{array}{l}0.707082(5) \\
0.707125(6)\end{array}$ \\
\hline CA16 & $\begin{array}{l}\text { Salar de Anto- } \\
\text { falla }\end{array}$ & $\begin{array}{l}26^{\circ} 20^{\prime} 15.6^{\prime \prime} \mathrm{S} \\
68^{\circ} 00^{\prime} 55.0^{\prime \prime} \mathrm{W}\end{array}$ & & $\begin{array}{l}\text { S28 } \\
\text { S29 }\end{array}$ & & & & & $\begin{array}{l}0.708851(5) \\
0.709181(6)\end{array}$ \\
\hline CA17 & $\begin{array}{l}\text { Salt pond ignim- } \\
\text { brite field }\end{array}$ & $\begin{array}{l}25^{\circ} 47^{\prime} 42.2^{\prime \prime} \mathrm{S} \\
68^{\circ} 22^{\prime} 40.2^{\prime \prime} \mathrm{W}\end{array}$ & & S30 & & & & & $0.708508(5)$ \\
\hline CA18 & $\begin{array}{l}\text { Salar de Uyuni } \\
\text { (1) } \\
\text { Ojos del Salar }\end{array}$ & $\begin{array}{l}20^{\circ} 18^{\prime} 43.0^{\prime \prime} \mathrm{S} \\
66^{\circ} 59^{\prime} 50.0^{\prime \prime} \mathrm{W}\end{array}$ & BU2 & & $13.3(1)$ & 439 & $1.0(0)$ & 517 & $0.710604(8)$ \\
\hline CA19 & $\begin{array}{l}\text { Salar de Uyuni } \\
\text { (2) } \\
\text { Cerro Tunupa }\end{array}$ & $\begin{array}{l}19^{\circ} 54^{\prime} 26.4^{\prime \prime} \mathrm{S} \\
67^{\circ} 41^{\prime} 03.3^{\prime \prime} \mathrm{W}\end{array}$ & BU4 & & $13.9(1)$ & 446 & $-2.0(1)$ & 323 & $0.708116(7)$ \\
\hline
\end{tabular}

Uncertainties are valid for the last digits

Locations for Google Earth in ESM2

of the brines are related to evaporation and increases with the total cation load. Saturation appears to be reached at loads around $5 \mathrm{~mol} / \mathrm{l}$, but $\mathrm{Li}$ (and also $\mathrm{K}$ ) further enriches in the residual brine, because it prefers the brine over the salt (ESM1 Fig. A4). The Li content in the salts is variable and distribution coefficients for Li between brine-salt pairs 
are 17.5 and 16.2 at locations (sp) 1 and 3 in the centre and 4.4 at location 10 near the rim of the salar. The precipitates (solid salt) in the brine ponds and pools, are mainly halite (four of five samples have $\mathrm{NaCl}$ contents of 98 to $99 \%$, one sample 96\%). Li contents are variable, ranging between 57 and $140 \mu \mathrm{g} / \mathrm{g}$ in the salt from natural brine ponds, and reaching up to $1040 \mu \mathrm{g} / \mathrm{g}$ in a dendritic salt sample from an artificial brine pool. A salt sample from a completely evaporated artificial pool shows a $\mathrm{Li}$ concentration of $340 \mu \mathrm{g} / \mathrm{g}$. The salt of core $\mathrm{L} 01$ contains 99 to $100 \% \mathrm{NaCl}$, i.e. is supposed to be nearly pure halite. Li concentrations are generally lower than in the surface salts, ranging between 6 and $63 \mu \mathrm{g} / \mathrm{g}$ and clustering between 30 and $50 \mu \mathrm{g} / \mathrm{g}$.

\section{Oxygen and hydrogen isotope composition of the surface brines}

Oxygen and hydrogen compositions of the brines vary in $\delta^{18} \mathrm{O}$ values between -6 and $+11 \%$ and in $\delta^{2} \mathrm{H}$ values between -68 and $-17 \%$; the spring fluid is somewhat different with $\delta^{18} \mathrm{O}$ values of $-10 \%$ and $\delta^{2} \mathrm{H}$ of $-95 \%$ o (Fig. 2). The values of the brines deviate in a linear array from the Global Meteoric Water Line (GMWL; $\delta^{2} \mathrm{H}=8^{*}$ $\delta^{18} \mathrm{O}+10$; Craig 1961) and the Local Meteoric Water Line (LMWL; $\delta^{2} \mathrm{H}=7.8^{*} \delta^{18} \mathrm{O}+9.7$; Aravena et al. 1999) for Northern Chile (Fig. 2). Such arrays of data with slopes that are less steep than the meteoric water line are typical of evaporation (e.g. Fiorella et al. 2015 for the Central Andes) and follows the trend observed for other high-altitude basins in the Central Andes (e.g. Godfrey et al. 2013; Orberger et al. 2015). There is no simple covariation with the progress

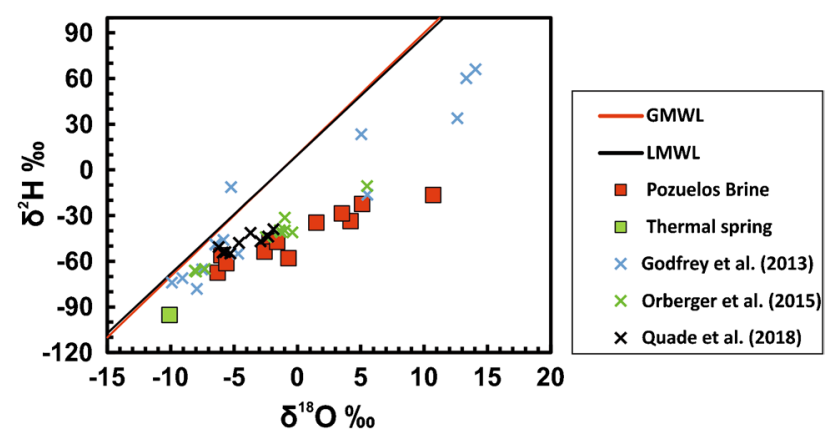

Fig. $2 \mathrm{O}$ and $\mathrm{H}$ isotope composition of brines from the Salar de Pozuelos and other salar settings of the Central Andes. Datasets from various restricted basins in the arid Central Andes define different evaporation trends. The Global Meteoric Water Line (GMWL) and the Local Meteoric Water Line (LMWL) for Northern Chile are similar. Intercepts of regression lines for different evaporation trends and LMWL are between $\delta^{18} \mathrm{O}$ values of -11.2 and $-11.9 \%$ for the high altitude basins (Salar de Pozuelos; Salar de Hombre Muerto, Godfrey et al. 2013; Salar de Ratones-Centenario, Orberger et al. 2015) and-9.5\% for Salar de Atacama (Quade et al. 2015). The intercepts with LMWL are within the range of isotopic composition of rain at the respective altitudes (Fiorella et al. 2015) of evaporation seen in the oxygen isotopes and $\mathrm{Li}$ contents (ESM1 Fig. A4).

\section{Lithium and Sr isotope compositions}

\section{Salar deposits: surface brines and evaporites}

Brines collected at the surface show ranges of $\delta^{7} \mathrm{Li}$ values between +15.4 and $+19.3 \%$ and ${ }^{87} \mathrm{Sr} /{ }^{86} \mathrm{Sr}$ between 0.7108 and 0.7149 ; salts show ranges of +16.5 to $+17.3 \%$ and 0.7119 to 0.7125 . Brine-salt pairs from the same ponds show no differences between their $\delta^{7} \mathrm{Li}$ values within the overlapping uncertainties, but the average $\delta^{7} \mathrm{Li}$ of the brines are slightly higher by 0.1 to $0.2 \%$ o than the average of the coexisting salts. The ${ }^{87} \mathrm{Sr} /{ }^{86} \mathrm{Sr}$ of the brine-salt pairs is indistinguishable within the external reproducibility of the NIST 987 reference material of $14 \mathrm{ppm}\left(2 \mathrm{sd}_{\text {mean }}\right)$. In the hydrothermal spring location, the spring fluid shows a $\delta^{7} \mathrm{Li}$ value of $+11.4 \%$, with a $\mathrm{Li}$ concentration of $9 \mu \mathrm{g} / \mathrm{g}$ and $\mathrm{Sr}$ isotope signature of 0.7197 . The travertine ranges from -0.07 to $+1.3 \%$ (average $0.7 \pm 1(2 \mathrm{sd}), n=8$ ) in $\delta^{7} \mathrm{Li}$, with $\mathrm{Li}$ concentrations between 3 and $17 \mu \mathrm{g} / \mathrm{g}$, and ${ }^{87} \mathrm{Sr} /{ }^{86} \mathrm{Sr}$ between 0.7168 and 0.7247 . The $\delta^{7} \mathrm{Li}$ and ${ }^{87} \mathrm{Sr} /{ }^{86} \mathrm{Sr}$ of the travertine are positively correlated $\left(p^{<} 0.05\right)$, whereas covariation of $\mathrm{Sr}$ and $\mathrm{Li}$ isotope composition is absent in all other sample groups. The offset in the $\delta^{7} \mathrm{Li}$ value between the travertine and the spring fluid is $-10.7 \%$ o. Salts of the upper $95 \mathrm{~m}$ of the core $\mathrm{L} 01$ show small ranges in $\delta^{7} \mathrm{Li}$ values between +16.0 and $+17.0 \%$ and in ${ }^{87} \mathrm{Sr} /{ }^{86} \mathrm{Sr}$ between 0.7133 and 0.7151 (Fig. 3). Two borate (ulexite) samples have $\delta^{7} \mathrm{Li}$ values of +8.2 and $+12.4 \%$ and ${ }^{87} \mathrm{Sr} /{ }^{86} \mathrm{Sr}$ of 0.7152 and 0.7154 , respectively. There is no covariation between $\mathrm{Li}$ contents and $\delta^{7} \mathrm{Li}$ values in any of the sample groups (ESM1 Fig. A5).

\section{Salar deposits: siliciclastic sediments and their water-soluble fractions}

The $\delta^{7} \mathrm{Li}$ values, $\mathrm{Li}$ contents and ${ }^{87} \mathrm{Sr} /{ }^{86} \mathrm{Sr}$ of siliciclastic sediments from the border region of the salar (SP-11-18, 28, $31 \mathrm{~A}$ and B) vary between -3.6 and $+0.8 \%$, 47 and $590 \mu \mathrm{g} / \mathrm{g}$ and 0.7110 and 0.7151 . Compositions of core DDH1 and SP-11-7 range in the sand-rich fraction from -2.3 to $-0.1 \%$ o, 63 to $322 \mu \mathrm{g} / \mathrm{g}, 0.7113$ to 0.7157 and in the clay-rich fraction from -3.7 to $-0.6 \%$ o, 193 to $370 \mu \mathrm{g} / \mathrm{g}$, 0.7127 to 0.7237 . The water-soluble fractions of the core DDH1 show $\delta^{7} \mathrm{Li}$ values between +16.0 and $+17.5 \%$ o, $\mathrm{Li}$ concentrations of 248 to $935 \mu \mathrm{g} / \mathrm{g}$, and ${ }^{87} \mathrm{Sr} /{ }^{86} \mathrm{Sr}$ of 0.7119 to 0.7125 . The water-soluble fraction of surface sediment SP-11-7 from the centre of the salar shows values of $+17.3 \%, 74 \mu \mathrm{g} / \mathrm{g}$ and 0.7119 , and the isotopic composition is indistinguishable from DDH1 (Fig. 3). 


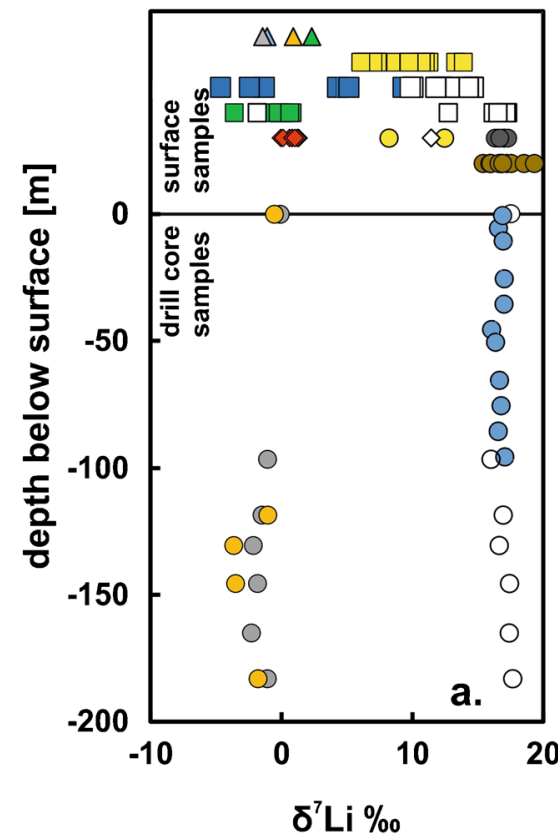

Fig. 3 Lithium (a) and $\mathrm{Sr}$ (b) isotopic compositions of sedimentary rocks from the catchment area, salt, brines, siliciclastic sediments and their water-soluble fractions from the Salar's surface and drill holes (L01; DHH1), and survey samples (spring water, brines) from the LiTriangle with the two highest $\delta^{7} \mathrm{Li}$ values from Salar de Uyuni. For comparison, average (av.) compositions of locally (catchment area, Cenozoic sedimentary rocks) and regionally (Altiplano-Puna Plateau) important source rocks are shown (values of the regional rock averages are given in text and are taken from Meixner et al. 2020; $\delta^{7} \mathrm{Li}$ and ${ }^{87} \mathrm{Sr} /{ }^{86} \mathrm{Sr}$ values: Cenozoic sediments $+6.2 \pm 10 \%$; $0.715 \pm 0.006$ (2sd), silicic (large-volume) ignimbrites $-1.4 \pm 7 \%$; $0.710 \pm 0.001$ (2sd), CVZ andesite $+2.3 \pm 4 \% o, 0.707 \pm 0.001$ (2sd), Ordovician sedimentary rocks $-1.1 \pm 2 \%$ o, $0.750 \pm 0.05$ ( $2 \mathrm{sd})$, Palaeozoic magmaticmetamorphic basement $+0.9 \pm 3 \%, 0.755 \pm 0.04(2 \mathrm{sd})$ ). 'Ord' marks

\section{Salar catchment area: siliciclastic sediments and igneous rocks and their water-soluble fractions}

The $\mathrm{Li}$ and $\mathrm{Sr}$ isotope composition of the sedimentary rocks (washed) is quite variable, including three Oligocene $\left(\delta^{7} \mathrm{Li}=+4.3,+4.9,+9.3 \%\right.$; $\mathrm{Li}=29,34,26 \mu \mathrm{g} / \mathrm{g}$; $\left.{ }^{87} \mathrm{Sr} /{ }^{86} \mathrm{Sr}=0.7149,0.7180,0.7139\right)$ and one Eocene $(+12.8 \% 0 ; 25 \mu \mathrm{g} / \mathrm{g} ; 0.7175)$ sample, and a recent sediment from a dry drainage channel SP-11-20 $(-0.3 \%$; $25 \mu \mathrm{g} / \mathrm{g} ; 0.7114)$. The water-soluble fractions show also considerable variations $\left(\delta^{7} \mathrm{Li}=+14.7,+10.0,+22.9\right.$ $\%$; $\mathrm{Li}=394,1271,39 \mu \mathrm{g} / \mathrm{g} ;{ }^{87} \mathrm{Sr} /{ }^{86} \mathrm{Sr}=0.7106,0.7105$, $0.7113)$ in the Oligocene samples, $(+12.2 \% \circ ; 4.3 \mu \mathrm{g} / \mathrm{g}$; $0.7156)$ in the Eocene and in the unconsolidated sediment $(-1.9 \% \circ ; 1.1 \mu \mathrm{g} / \mathrm{g} ; 0.7109)$. The fresh and altered ignimbrite samples show $\delta^{7} \mathrm{Li}$ values of -4.7 and $-2.5 \%$, $\mathrm{Li}$ concentrations of 24 and $28 \mu \mathrm{g} / \mathrm{g}$; and ${ }^{87} \mathrm{Sr} /{ }^{86} \mathrm{Sr}$ of 0.7111 , respectively. The associated water-soluble fraction has $\delta^{7} \mathrm{Li}$ values of +9.8 and $+12.8 \%$ o, $\mathrm{Li}$ concentrations of 4.8 and $3.1 \mu \mathrm{g} / \mathrm{g}$, and ${ }^{87} \mathrm{Sr} /{ }^{86} \mathrm{Sr}$ of 0.7103 and 0.7103 . The the local sample of the Ordovician sedimentary rock in the group of 'sedimentary rocks' in the catchment area. The Li isotope composition is uniform with depth and the main compositional difference occurs between the group of siliciclastic fractions and the groups of brine, water-soluble fraction, and salt in the Salar. ${ }^{87} \mathrm{Sr} /{ }^{86} \mathrm{Sr}$ of salts from L01 are slightly higher than in the water-soluble fraction DDH1. The variability of ${ }^{87} \mathrm{Sr} /{ }^{86} \mathrm{Sr}$ is generally higher in the clay- and sandrich fraction and the clay-rich fraction scatters towards higher values. Influence of radiogenic $\mathrm{Sr}$ isotope compositions of the Palaeozoic basement (local 'Ord' Ordovician sedimentary rock in the catchment area) on the young salar deposits is generally small and highest in the travertine. ${ }^{87} \mathrm{Sr} /{ }^{86} \mathrm{Sr}$ of the survey samples (Li-Triangle) reflects their position within the active magmatic arc of the $\mathrm{CVZ}$

Ordovician sedimentary rock of the Palaeozoic basement, has a $\delta^{7} \mathrm{Li}$ value of $-1.3 \%$, Li of $31 \mu \mathrm{g} / \mathrm{g}$ and ${ }^{87} \mathrm{Sr} /{ }^{86} \mathrm{Sr}$ of 0.7312 (Meixner et al. 2020), and a water-soluble fraction with a $\delta^{7} \mathrm{Li}$ value of $+15.7 \%$, Li of $66 \mu \mathrm{g} / \mathrm{g}$ and ${ }^{87} \mathrm{Sr} /{ }^{86} \mathrm{Sr}$ of 0.7267 .

\section{Radiogenic ( $\mathrm{Nd}, \mathrm{Pb}, \mathrm{Sr}$ ) isotope composition of siliciclastic sediments of the salar basin and catchment area}

Strontium, neodymium and lead isotope compositions of siliciclastic sediments of the salar basin and sedimentary rocks of the catchment area are within the range of typical large-volume ignimbrite of the Central Andes and show little influence in their $\mathrm{Sr}$ isotope composition by signatures of the local (salar catchment area) and regional (Altiplano-Puna Plateau) Palaeozoic basement (ESM1 Fig. A6). 


\section{Elemental content and $\mathrm{Li}$ and Sr isotopic composition of samples from the Li-Triangle}

Sodium in the brine samples comprises 66 to $98 \%$ of the analysed ( $\mathrm{Na}, \mathrm{K}, \mathrm{Li}, \mathrm{B}, \mathrm{Ca}, \mathrm{Mg}, \mathrm{Sr}$ ) dissolved cations in the brines with only one sample being as low as $28 \%$ (spring water from Quebrada Chaco del Norte in Chile). The Li contents of the fluids ranges from 1.2 to $600 \mathrm{mg} / \mathrm{L}$, showing a positive correlation $\left(p^{<} 0.05\right)$ between $\mathrm{Li}$ and $\mathrm{Na}$, i.e. an evaporation trend. The $\delta^{7} \mathrm{Li}$ values are between +6.0 and $+13.9 \%$ and are hence, significantly lower than the Pozuelos brines, but in the range of fluids observed from other salars in the Central Andes, such as Hombre Muerto, Ratones and Centenario, and Olaroz (Godfrey et al. 2013; Orberger et al. 2015; Garcia et al. 2020). The ${ }^{87} \mathrm{Sr} /{ }^{86} \mathrm{Sr}$ of the fluid samples vary between 0.7064 and 0.7098 , nearly perfectly correlated $\left(p^{<} 0.05\right)$ with the values $(0.7062$ to 0.7097) from the associated salt samples. Since brine-salt pairs show no differences between their $\delta^{7} \mathrm{Li}$ values within uncertainties, we only analysed the salt's $\mathrm{Sr}$ isotope composition. Salt samples without paired fluids show a similar range in ${ }^{87} \mathrm{Sr} /{ }^{86} \mathrm{Sr}$ from 0.7071 to 0.7104 .

\section{Boron concentration and isotope composition of the surface brines and salts from the surface, core L01 and samples from the Li-Triangle}

The boron concentrations of the surface brines range from 15 to $490 \mu \mathrm{g} / \mathrm{g}$ with a total range in the B isotopic compositions from -19.3 to $-1.8 \%$ (Fig. 4). The boron concentration for the salt (31 to $540 \mu \mathrm{g} / \mathrm{g}$ ) is similar to the surface brines, but the range in $\delta^{11} \mathrm{~B}$ is more restricted to values between -19.9 and $-8.5 \%$ o, (average $-15.8 \%$ o $\pm 8.6,2 \mathrm{sd}$ ). The salt from L01 show the most homogeneous $\delta^{11} \mathrm{~B}$ values with an average similar to the surface salts of $-15.8 \pm 2.4$ ( $2 \mathrm{sd}, n=11$ ). The $\mathrm{B}$ concentration ranges from 11 to $423 \mu \mathrm{g} / \mathrm{g}$. The travertine shows the most negative $\delta^{11} \mathrm{~B}$ value of about $-23.5 \%$ and two borate minerals show $\delta^{11} \mathrm{~B}$ values

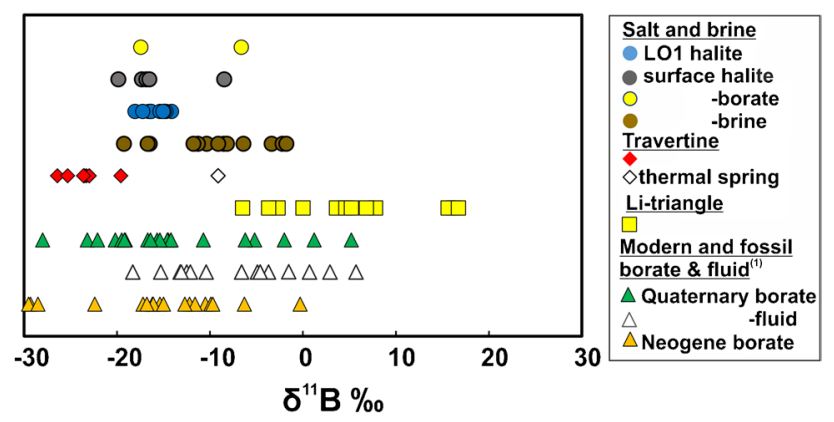

Fig. 4 Boron isotope composition of salt, brine and travertine from the Salar de Pozuelos and published data from Puna salars and Puna fossil borate deposits. (1) Kasemann et al. (2000, 2004) of $-17.5 \%$ and $-6.7 \%$. The B concentration for the fluid samples of the survey samples from the Li-Triangle ranges from 0.5 to $1390 \mathrm{mg} / \mathrm{L}$, with the brine samples showing the highest values and spring samples reaching maximum values of $50 \mathrm{mg} / \mathrm{L}$. The total range in the B isotopic compositions is again quite substantial $(-6.5$ to $+16.7 \%$ ) but more positive compared to the Salar de Pozuelos samples.

\section{Discussion}

\section{Sources of the Li in the Salar de Pozuelos-Sr isotope composition}

Aqueous solutions entering the salar reflect the strontium isotope signatures of their sources and the isotopic signature of brine and salt deposits is governed by mixing of different ${ }^{87} \mathrm{Sr} /{ }^{86} \mathrm{Sr}$ source-compositions during transport and post depositional processes in the salar. Incongruent, mineralspecific weathering of low and high $\mathrm{Rb} / \mathrm{Sr}$ minerals from young, Andean magmatic rocks has minor influence on the $\mathrm{Sr}$ isotope signature of aqueous solutions, but the influence may be large from selective weathering of such minerals from Ordovician basement rocks. The latter have a given lower limit of Sr isotope signatures for incongruent weathering of a hypothetical very low $\mathrm{Rb}$ mineral by their average initial ${ }^{87} \mathrm{Sr} /{ }^{86} \mathrm{Sr}$ of 0.715 ; the average modern ${ }^{87} \mathrm{Sr} /{ }^{86} \mathrm{Sr}$ for the case of congruent weathering is 0.759 (Egenhoff and Lucassen 2003). However, the ${ }^{87} \mathrm{Sr} /{ }^{86} \mathrm{Sr}$ for our brine and salt samples are not higher than 0.715 but generally lower in most samples, the exclusive origin of $\mathrm{Sr}$ from a very low $\mathrm{Rb}$ mineral of the Ordovician basement rocks is highly unlikely, and the agreement with the isotopic values of the young siliciclastic salar sediments and the outcropping Andean rock associations present in the catchment area and in the Altiplano-Puna Plateau is very good (Fig. 3; ESM1 Fig. A6, ESM4). Hence, we preclude the Ordovician as the major source of $\mathrm{Sr}$ in the Salar.

The $\mathrm{Sr}$ isotope signatures of the rock inventory in the Central Andes are well known and distinguish sharply between the major rock sources. The combined $\mathrm{Sr}$ and $\mathrm{Nd}$ isotopic signatures of the rocks provide an even better tool to identify the sources (ESM1 Fig. A6). The surface geology in the catchment area of Pozuelos is dominated by Ordovician sedimentary rocks, partly covered by much younger Eocene to Miocene, and Quaternary sedimentary rocks (Fig. 1). Apart from documented tuff layers in these young rocks (Blasco et al. 1996), we assume a frequent widespread supply of volcanic materials from air-falls during eruptions of andesitic stratovolcanoes and ignimbrite flare-ups or windblown volcanic detritus from the still active magmatic arc that is stored and hidden in the young colluvial/alluvial deposits. Besides isolated intrusions of Miocene igneous 
rocks in the catchment area of Pozuelos (Blasco et al. 1996), relicts of massive ignimbrite exists in the vicinity around the Salar according to mapping of the surface distribution of such rocks in the Puna Plateau (Brandmeier and Wörner 2016) and own observations. The surface geology is underlain by the Palaeozoic basement.

We use the ${ }^{87} \mathrm{Sr} /{ }^{86} \mathrm{Sr}$ compositions of the local (Salar de Pozuelos catchment area) and regional (Altiplano-Puna Plateau) rock inventory to characterise the siliciclastic source rocks of Li deposited in evaporites of the Pozuelos. The regional averages refer to Palaeozoic basement rocks and Cenozoic volcanic rocks from the Central Andean arc with already analysed Li isotope compositions (Fig. 3a; Meixner et al. 2020). In the catchment area of Pozuelos, the ${ }^{87} \mathrm{Sr} /{ }^{86} \mathrm{Sr}$ of the local Ordovician sedimentary rock (0.731) and the ignimbrite $(0.711)$ falls within the regional average of the Palaeozoic sedimentary-metamorphic-magmatic basement $(0.754 \pm 0.04(2 \mathrm{sd}), n=27)$ and the regional averages of Cenozoic andesite $(0.707 \pm 0.001(2 \mathrm{sd}), n=21)$ and ignimbrite $(0.710 \pm 0.001(2 \mathrm{sd}), n=11)$, respectively. The ${ }^{87} \mathrm{Sr} /{ }^{86} \mathrm{Sr}$ composition of the local Cenozoic sediments of the catchment area is 0.711 to $0.718(0.715 \pm 0.006(2 \mathrm{sd}), n=5)$ and not dominated by the abundant Ordovician sedimentary rock, but similar to the composition of Cenozoic ignimbrite.

The siliciclastic sediments from the salar deposits, including clay- and sand-rich fractions of DDH1 (average ${ }^{87} \mathrm{Sr} /{ }^{86} \mathrm{Sr} 0.715, n=13$ ), resemble the composition of Cenozoic sedimentary rocks from the catchment area (Fig. 3; ESM1 Fig. A6). The small range of Nd isotope signatures of catchment area $(0.5122 \pm 0.00012 \mathrm{sd}, n=7)$ and salar siliciclastic rocks $(0.5122 \pm 0.00012 \mathrm{sd}, n=15)$ is not correlated with the more variable ${ }^{87} \mathrm{Sr} /{ }^{86} \mathrm{Sr}$ and both resemble the variation in regional large volume ignimbrite (ESM1 Fig. A6). The sand-rich fraction of DHH1 shows a small range of ${ }^{87} \mathrm{Sr} /{ }^{86} \mathrm{Sr}$ (0.711 to 0.716 ; average $\left.0.713, n=7\right)$ and the clay-rich fraction is slightly more radiogenic $(0.713$ to 0.724 ; average $0.717, n=5$ ). We speculate that detrital micas of the Ordovician sedimentary rocks with high ${ }^{87} \mathrm{Sr} /{ }^{86} \mathrm{Sr}$ are variable in occurrence, but in small amounts enriched in the clay-rich fraction. This could also explain the uniform $\mathrm{Nd}$ and variable $\mathrm{Sr}$ isotope composition of $\mathrm{DHH} 1$, due to the generally low rare earth element contents of micas.

Quantification of distinct components remains ambiguous considering the potential addition of high ${ }^{87} \mathrm{Sr} /{ }^{86} \mathrm{Sr}$ micas from the Palaeozoic basement, e.g. the Ordovician sedimentary rocks. Mixing models have to consider the uniformity of $\mathrm{Nd}$ isotope signatures in the siliciclastic fractions of DHH1, other salar sediments, and in the Cenozoic cover (ESM1 Fig. A6). Binary mixing between an ignimbrite endmember $\left({ }^{87} \mathrm{Sr} /{ }^{86} \mathrm{Sr}\right.$ of $0.710, \mathrm{Sr}$ of $250 \mu \mathrm{g} / \mathrm{g}$; ignimbrite database from Brandmeier and Wörner 2016) and Ordovician sedimentary rocks $\left({ }^{87} \mathrm{Sr} /{ }^{86} \mathrm{Sr}\right.$ of 0.75 , Sr of $70 \mu \mathrm{g} / \mathrm{g}$; Egenhoff and Lucassen 2003) requires 0 to $20 \% \mathrm{Sr}$ of bulk Ordovician (one clay-rich sample of DDH1 requires about $30 \%$ bulk Ordovician) to explain the observed ${ }^{87} \mathrm{Sr} /{ }^{86} \mathrm{Sr}$ compositional range of the Cenozoic siliciclastic sediments.

The $\mathrm{Sr}$ isotope compositions of salts and brines from the Salar de Pozuelos reflect the signatures of the hydrous influx into the salar and potential processes of homogenisation of the solutions. All brines and salts from the surface, core L01, and water-soluble fraction of DHH1 $(0.713 \pm 0.003$ (2sd), $n=34$ ) plot in general on the local and regional 'ignimbrite averages' of Sr isotope composition and within the compositional range of the Cenozoic sedimentary rocks and their water-soluble fractions (Fig. 3; ESM1 Fig. A6). Signatures of the water-soluble fractions of DHH1 (i.e. salt, indicated as salt in the table) are more homogeneous, generally less radiogenic (average of $0.7121 \pm 0.0005,2 \mathrm{sd}$ ) and hence, not related to the more radiogenic signatures $(0.715 \pm 0.006$, $2 \mathrm{sd})$ of their silicate hosts. The isotopic signature of the surface salts $(0.7123 \pm 0.0005,2 \mathrm{sd})$ is similar to the water-soluble fraction. The small variability of actual surface brines from the salar's border $(0.713 \pm 0.005,2 \mathrm{sd})$ is likely caused by variations in their source contributions. In contrast, the smaller compositional spread in the salt and water-soluble fractions of the cores points to a time-integrated homogenisation of the run-off from different silicate sources during leaching, transport and precipitation of the evaporite deposit. The ${ }^{87} \mathrm{Sr} /{ }^{86} \mathrm{Sr}$ in surface brines (except SP-11-14 and SP-11-21), the water-soluble fractions of core DDH1, and surface sediment (SP-11-7) are slightly less radiogenic (lower) than in the salts of the core L01 (Fig. 3b). Sample sites (sp 8,13) of brine SP-11-14 and SP-11-21 border to an extended outcrop of Ordovician rocks and seem to reflect the radiogenic ${ }^{87} \mathrm{Sr} /{ }^{86} \mathrm{Sr}$ of this proximal source (Fig. 1). The ${ }^{87} \mathrm{Sr} /{ }^{86} \mathrm{Sr}$ of SP-11-14 is lower than of SP-11-21, which locates closer to the spring and travertine deposit. The spring and the related travertine is hosted in the faulted contact between the Ordovician and Eocene rocks and samples slightly variable amounts of radiogenic Sr over time as seen in the travertine (Fig. 3b; ESM1 Fig. A6). The slight but systematic offset to more radiogenic ${ }^{87} \mathrm{Sr} /{ }^{86} \mathrm{Sr}$ in the halite from core L01 could be caused by a higher contribution of runoff from the Ordovician potentially including enhanced hydrothermal activity in the past with radiogenic ${ }^{87} \mathrm{Sr} /{ }^{86} \mathrm{Sr}$ as seen in the travertine and related spring.

On the base of the similar $\mathrm{Sr}$ isotope signatures in evaporite and Cenozoic siliciclastic sediments within the salar and in the catchment area, we favour a dominantly ignimbrite source rock (binary mixing of about 70 to $100 \%$ ignimbrite component and 0 to $30 \%$ Ordovician sedimentary rocks, as discussed above), even if at present no significant amount of ignimbrites are exposed in the catchment area. However, the ignimbrite deposits of the Central Andes are among the largest on Earth, with volumes up to several thousands of cubic kilometres and 
covering areas of over $10,000 \mathrm{~km}^{2}$ (e.g. Brandmeier and Wörner 2016). In addition, aeolian erosion and transport of e.g. poorly indurated ignimbrite are well described (Mandt et al. 2008). Moreover, the Altiplano and the Puna are areas with important dust activity year round (Prospero et al. 2002), potentially since the Late Pliocene age (Goudie and Wells 1995). Thus, a possible scenario includes volcanic detritus deposition either from airfall or windblown. The volcanic detritus at the surface is also easily transported and potentially accumulated in the young, poorly solidified sedimentary cover, and in the salar basin as evidenced by the composition of siliciclastic salar sediments (Fig. 3b; ESM1 Fig. A6). Such volcanic material is much more sensitive to chemical weathering, due to the large surface and high glass contents (Ruggieria et al. 2010), than the well-solidified massive Ordovician sedimentary rocks.

The $\mathrm{Sr}$ isotope composition of the basin sedimentary material and fluids could also be produced by mixing approximately 35 to $60 \%$ andesite (Meixner et al. 2020 with references herein) with 40 to $65 \%$ Pz-basement. We, however, consider this scenario as less likely. Andesite deposits are not known in the catchment area, and while aeolian transport and deposition of eroded material is possible, the andesites are mostly deposited as lavas produced from stratovolcanoes and monogenetic centres and less prone to erosion than the poorly indurated ignimbrite. In addition, a relative high input of Pz-basement material, the dominant rock lithology (Ordovician sedimentary rock) in the catchment area is necessary for this scenario not only for the addition of $\mathrm{Sr}$, but also to deliver a considerable amount of $\mathrm{Li}$. The host of Li in the Ordovician sedimentary rocks are most likely micas and K-feldspars with a radiogenic $\mathrm{Sr}$ isotope composition. An increased input of these minerals would drive the $\mathrm{Sr}$ isotope composition of the siliciclastic sediments in the basin to more radiogenic values, a situation that is not observed.

\section{Sources of the Li in the Salar de Pozuelos-Li isotope composition}

Silicate minerals are the principal primary host of $\mathrm{Li}$ (Teng et al. 2004) and weathering or hydrothermal leaching are the principal processes of mobilisation of Li from the silicate. The extent of fractionation of the $\mathrm{Li}$ isotope composition depends on the weathering process. Chemical weathering with bulk solution transfers the $\delta^{7} \mathrm{Li}$ signature of host minerals to the solute. In contrast, higher $\delta^{7} \mathrm{Li}$ in solutes depends on the extent of secondary mineral formation in the source rock, during transport, as well as in the deposit area by sequestration of ${ }^{6} \mathrm{Li}$ in secondary clay minerals (e.g. Pistiner and Henderson 2003; Kisakurek et al. 2004; Vigier et al. 2008; Wimpenny et al. 2010; Hindshaw et al. 2019; recent summaries provided by Tomascak et al. 2016; Pogge von Strandmann et al. 2016; Weynell et al. 2017). The fractionation of $\mathrm{Li}$ isotopes in hydrothermal systems depends, e.g. on the temperature of the fluid/rock reaction and related formation and stability of secondary minerals. The fractionation, i.e. $\delta^{7} \mathrm{Li}$ in the fluid from natural and experimental hydrothermal systems, is generally inversely correlated with $\mathrm{T}$ and approaches the composition of the host rocks at high T (e.g. Millot and Négrel 2007; Millot et al. 2010; Henchiri et al. 2014; Pogge von Strandmann et al. 2016; Cullen et al. 2019: recent summary Tomascak et al. 2016). A hydrothermal spring compositional field was denoted with $\delta^{7} \mathrm{Li}>0$ and $<11 \%$ (Pogge von Strandmann et al. 2016 and references therein), a range which encompasses many of the $\delta^{7} \mathrm{Li}$ data in hydrothermal fluids and salar deposits in the Central Andes (see below).

The siliciclastic Ordovician sedimentary rock sample from the Salar de Pozuelos catchment shows a $\delta^{7} \mathrm{Li}$ value of $-1.3 \%$, which is within the regional (Altiplano-Puna Plateau) average of $-1.1 \pm 2 \%$ ( 2 sd, $n=15$; Meixner et al. 2020) for Ordovician sedimentary rocks and similar to the regional average of $+0.9 \pm 3 \%$ o (2sd, $n=15$; Meixner et al. 2020) for the Palaeozoic magmatic-metamorphic basement. The Ordovician sedimentary rocks are the dominant surface rocks in the Salar de Pozuelos catchment area and partly covered by Cenozoic sediments with a range in $\delta^{7} \mathrm{Li}$ value from -0.3 to $+12.8 \%$ o $\left(\delta^{7} \mathrm{Li}\right.$ average of $+6.2 \pm 10 \%$ o $(2 \mathrm{sd}), n=5)$. Outcrops of volcanic rocks in the catchment area (local) are restricted to small occurrences of ignimbrite, but influx of detritus from the active arc as ash-fall or windblown material is potentially important. The $\mathrm{Li}$ isotope composition of two local ignimbrite samples are -2.5 and $-4.7 \%$; the regional average of silicic (large-volume) ignimbrites is $-1.4 \pm 7 \%$ o (2sd, $n=10)$ and $+2.3 \pm 4 \%$ ( $2 \mathrm{sd}, n=23)$ for Central Volcanic Zone (CVZ) andesites (Meixner et al. 2020).

The $\delta^{7} \mathrm{Li}$ values of brines and salts are in general uniform, pointing to negligible isotope fractionation during precipitation of salt from brine (Godfrey et al. 2013; this work), and higher compared to the values of potential source rocks, i.e. rocks from the catchment area and regional volcanic- and Pz-basement rocks (Fig. 3a; 


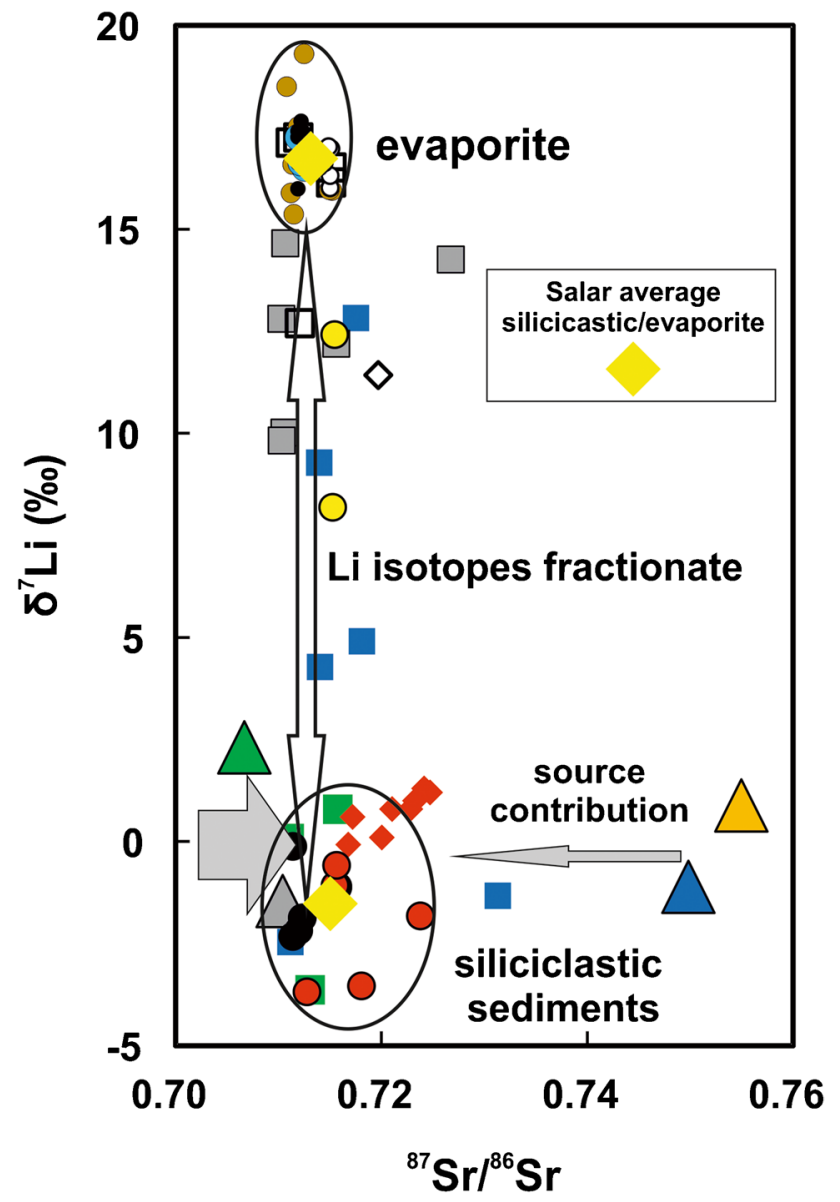

Fig. $5 \mathrm{Li}$ and $\mathrm{Sr}$ isotope compositions of the Salar de Pozuelos and evolution of the isotope signatures from source rocks to evaporite. According to the $\mathrm{Sr}$ isotope composition of siliciclastic sediments and evaporite in the salar, the contribution of Palaeozoic sources is small compared to the volcanic arc sources. Fractionation of Li isotopes: see the discussion. Labels, see Fig. 3

Fig. 5). The $\delta^{7} \mathrm{Li}$ values in surface brines and salts (average $+17 \pm 2 \%$ o (2sd), $n=17$ ) are similar to the values of the salts and water-soluble fractions in the drill holes (average $+16.8 \pm 0.9 \%$ o (2sd), $n=18$ ) but slightly more variable, which points to homogenisation of the more heterogeneous compositions from proximal sources within the salar (Fig. 3a). Thus, salts and brines of the salar deposits, including the water-soluble fraction of DHH1, show a uniform $\delta^{7} \mathrm{Li}$ composition in three dimensions. There is no covariation, i.e. a mixing relation between $\delta^{7} \mathrm{Li}$ and strongly variable Li concentrations (ESM1 Fig. A5). The concentrations are dominated by evaporation as corroborated by the oxygen isotope composition of the surface brines.
The spring fluid has a lower $\delta^{7} \mathrm{Li}$ value $(+11.4 \%$ o than the brines and salts. The offset in the $\delta^{7} \mathrm{Li}$ value of $-10.7 \%$ o between the travertine and the spring fluid is similar to what is observed for the isotope fractionation between inorganic aragonite and high-salinity fluids $\left(\Delta^{7} \mathrm{Li}\right.$ aragonite-artificial seawater of $-11 \%$, Marriott et al. $2004)$, pointing to original aragonite precipitation. To note is the low Li concentration of approximately $9 \mu \mathrm{g} / \mathrm{g}$ in both the fluid and the travertine. While the actual spring fluid might not represent the original concentration of the Li inflow via the former hot spring, the travertine documents a low Li concentration inflow in the basin and the necessary Li enrichment via evaporation. A Pleistocene travertine structure from the Salar de Hombre Muerto contains about $42 \mu \mathrm{g} / \mathrm{g}$ of lithium (Godfrey et al. 2013). The siliciclastic sediments associated with the evaporite deposit at surface and in the depth of the Salar de Pozuelos show consistently low $\delta^{7} \mathrm{Li}$ values between +0.8 and $-3.7 \%$ with an average of $-1.5 \pm 2.8 \%$ ( $2 \mathrm{sd} ; n=16)$. This average value is lower than the average of the continental crust with $\sim 0 \%$ o (Teng et al. 2004; Sauzéat et al. 2015) and regional andesite, but resembles closely the average of local and regional Ordovician sedimentary rocks and regional ignimbrite. The $\mathrm{Li}$ concentrations in the siliciclastic sediments are variable, but higher $(>47 \mu \mathrm{g} / \mathrm{g}<590 \mu \mathrm{g} / \mathrm{g}$; average $230 \pm 165 \mu \mathrm{g} / \mathrm{g}$, $n=16)$ than in average continental crust ( $30 \mu \mathrm{g} / \mathrm{g}$, Sauzéat et al. 2015; $35 \mu \mathrm{g} / \mathrm{g}$, Teng et al. 2004) or in the potential regional source rocks, i.e. andesite, ignimbrite and Ordovician sedimentary rocks (average: 21,27 , and $42 \mu \mathrm{g} / \mathrm{g}$; Meixner et al. 2020). The comparable high Li concentrations in the salar sediments and lower $\delta^{7} \mathrm{Li}$ values in four out of five clay-rich fractions point to secondary (clay) minerals (ESM1 Fig. A7).

If we tentatively consider the difference between the average $\delta^{7} \mathrm{Li}$ value of $+16.8 \%$ in the evaporite (i.e. the solution) and the salar siliciclastic sediments, assuming the $-1.5 \%$ average of the salar sediments as 'residue', the $\Delta^{7} \mathrm{Li}_{\text {residue-solution }}$ is $-18.3 \pm 1.4 \%$. This value is close to the difference of $-17.3 \%$ o between solids and small river solute from a global compilation (Hindshaw et al. 2019 and references therein), the experimental $\Delta^{7} \mathrm{Li}$ between clay minerals and solution of $-16.6 \% \circ\left(20^{\circ} \mathrm{C}\right.$; Hindshaw et al. 2019), and extrapolations of experimental data to temperatures down to $5{ }^{\circ} \mathrm{C}(\sim-19 \%$; Vigier et al. 2008). Such signatures were also observed in other catchment areasolution systems, e.g. with $\Delta^{7} \mathrm{Li}$ of $-17.8 \%$ in a similar weathering regime of the Himalayan (and elsewhere; Weynell et al. 2017 and references therein) and modelled (upper limit $-17 \%$ from reactive transport modelling for 
high-altitude catchment areas in the Himalayan, Bohlin and Bickle 2019). Thus, the observed $\delta^{7} \mathrm{Li}$ value of the evaporite deposits in Pozuelos indicates the dominance of near-surface chemical weathering with the formation of secondary clay minerals at low temperature. Bulk solution of Li-bearing silicate host does not fractionate $\mathrm{Li}$ and should reflect the source rock's $\delta^{7} \mathrm{Li}$.

In contrast, hydrothermal mobilisation of $\mathrm{Li}$ at some depth would cause variable but generally lower $\delta^{7} \mathrm{Li}$ values, due to the inhibited formation of secondary minerals at higher temperatures (range 1 to $11 \%$; Pogge von Strandmann et al. 2016 and references therein), than observed in the evaporites of Pozuelos (average of $+16.8 \%$ ). The actual
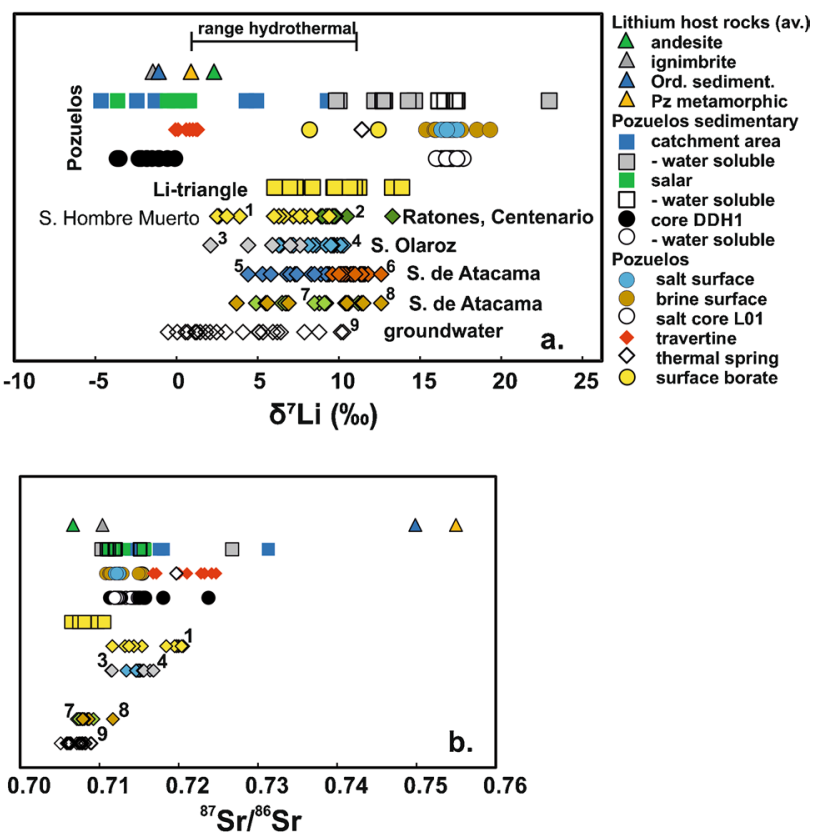

Fig. 6 Lithium and $\mathrm{Sr}$ isotope composition of source rocks, salar deposits, and (thermal) waters of the Central Andes. (a) $\delta^{7} \mathrm{Li}$ in the catchment area and salar deposits of Pozuelos, averages of potential regional source rocks of $\mathrm{Li}$ in the evaporite deposits (averages are taken from Meixner et al. 2020, and are given in the text and in Fig. 3), range of global hydrothermal waters (Pogge von Strandmann et al. 2016) and various regional evaporite deposits, potential feeders, thermal springs, and groundwater in the active arc of NE Chile around $22^{\circ} \mathrm{S}$. (b) ${ }^{87} \mathrm{Sr} /{ }^{86} \mathrm{Sr}$ composition. Numbers indicate the respective data sources. Data sources: average host rocks Meixner et al. (2020); Salar de Hombre Muerto (1) Godfrey et al. (2013); Salar de Ratones and Centenario (2) Orberger et al. (2015); Salar Olaroz $(3,4)$ Garcia et al. (2020) ((3) water surroundings of the salar; (4) brine); Salar de Atacama (5,6) Munk et al. (2018) ((5) water from feeders; (6) brine), (7,8) Godfrey and Álvarez-Amado (2020) ((7) groundwater from the surroundings of the salar; (8) brines from the adjacent border of the salar); ground water (9) Godfrey et al. (2019). For locations, see ESM2 Fig. A1 hydrothermal activity in the catchment area has ceased, and traces of former activity are restricted to one spring on the eastern side of the salar. If the $\mathrm{Li}$ isotope signatures of the spring fluid $(+11.4 \% o)$ and the travertine $(\sim 0$ to $+1.3 \%$ ) precipitated from the well are typical for the local thermal waters, then they remained near constant over the evolution of the well, and hydrothermal influx likely played a minor role in the $\mathrm{Li}$ (and $\mathrm{Sr}$ ) isotope budget of the evaporite in Pozuelos. Even if the range of $\delta^{7} \mathrm{Li}$ in travertine is small $(-0.1$ to $+1.3 \%$ o $)$, the values increase with variable radiogenic $\mathrm{Sr}$ from the Ordovician basement (Fig. 5), i.e. point to a weak influence of changing source contribution on the $\delta^{7} \mathrm{Li}$ values.

The most intriguing compositional feature of the Salar de Pozuelos basin is the small variation in ${ }^{87} \mathrm{Sr} /{ }^{86} \mathrm{Sr}$ signatures and the uniform high $\delta^{7} \mathrm{Li}$ values of salt precipitated from solutes in three dimensions of the deposit (Figs. 3 and 6). The age range represented by the drilled strata is unknown. Age models for cores in the Salar de Hombre Muerto (south of Pozuelos, catchment area $\sim 4000 \mathrm{~km}^{2}$, salar $\sim 600 \mathrm{~km}^{2}$ ) indicate ages of approximately $20 \mathrm{ka}$ at $8 \mathrm{~m}$ and up to $86 \mathrm{ka}$ at $40 \mathrm{~m}$ depth (estimate from the diagrams in Godfrey et al. 2003). Sedimentation in the large Salar de Atacama (surface $\sim 3000 \mathrm{~km}^{2}$; Alonso and Risacher 1996) is faster, with an estimated average rate of $0.9 \mathrm{~m} / \mathrm{kyr}$ and an age of $106 \mathrm{ka}$ at $100 \mathrm{~m}$ depth (Bobst et al. 2001) but represents a different depositional system compared with the conditions of the salars in the Puna Plateau. Even if we consider this fast deposition rate for the Salar de Pozuelos basin, the minimum age there at a depth of ca $100 \mathrm{~m}$ should be around $100 \mathrm{ka}$, and much older than $100 \mathrm{ka}$ at $183 \mathrm{~m}$, the lower end of the sampled core. The climate of the Puna Plateau and surroundings over the last 100,000 years included, compared with the present climate, various prolonged humid periods with glaciations around 13, 22 and $42 \mathrm{ka}$ on the now largely deglaciated plateau (e.g. Flores et al. 1997; Bobst et al. 2001; Placzek et al. 2009; Schildgen et al. 2016; D'Arcy et al. 2019). The $\delta^{7} \mathrm{Li}$ values of Pozuelos drill cores do not reflect any potential effects of changes in the weathering regime over time (Fig. 3a).

While the isotope composition of salts in the centre of the salar is uniform, the brines and the potential runoff from the catchment area are more variable in composition. Because availability of pluvial water is seasonal and restricted, we were not able to sample the runoff from the catchment area. We focussed instead on the water-soluble fraction of silicate rocks of the catchment area that shows a considerable scatter in $\delta^{7} \mathrm{Li}$ from +10 to $+23 \%$ with a range in isotope fractionation $\left(\Delta^{7} \mathrm{~L}_{\text {watersoluble-rock }}\right)$ from 0 
to $+17.5 \%$, assuming that the water-soluble $\mathrm{Li}$ is exclusively derived from the leached rock sample. The variability decreases in the surface brines $(+15.4$ to $+19.3 \%$ ) salts $(+16.3$ to $+17.3 \%)$, and water-soluble fraction $(+12.7$ to $+17.2 \%)$ of the siliciclastic material from the salar. The increasing uniformity in the $\delta^{7} \mathrm{Li}$ values, from the potential catchment runoff to the border and to the centre of the salar, indicates an increasing mixing and homogenisation of the Li signatures, a process that is also observed for the $\mathrm{Sr}$ isotope composition (Figs. 3 and 6). Mixing to the uniform composition is likely bound to occasional pluvial events that result in flooding of the salar's surface. Post depositional mixing of the entire volume of the salar seems unlikely because this would require dissolution of large volumes of halite, also in the siliciclastic sediments. Furthermore, slight systematic differences in the $\mathrm{Sr}$ isotope composition between the upper halite and salt (water-soluble fraction) from the lower siliciclastic section are preserved.

\section{Other salar deposits and thermal waters of the Central Andes}

Other salar deposits from the wider region, including our Li-Triangle data (mainly the salares of Atacama, Grande, Parina, Isla and Uyuni) show significantly lower $\delta^{7} \mathrm{Li}$ values than Pozuelos. The ranges of $\delta^{7} \mathrm{Li}$ values are large, but always higher than in the average regional source rocks, and most samples plot within the range of global hydrothermal waters (Fig. 6a). Only in a few samples, $\delta^{7} \mathrm{Li}$ values exceed $+11 \%$ and reach up to $+14 \%$.

In detail, most brines from Salar de Atacama show rather uniform $\delta^{7} \mathrm{Li}$ values from margin to core that range between +9.6 and $+12.6 \%$ o (Munk et al. 2018; this study) with generally lower values in feeders starting at $+4.4 \%$. This dataset is resembled by the range of $\delta^{7} \mathrm{Li}$ values between +3.7 and $+12.6 \%$ from feeder waters and marginal brines at the eastern edge of this salar (Godfrey and Álvarez-Amado 2020). Brines from Salar de Centenario, close to Pozuelos, show $\delta^{7} \mathrm{Li}$ values of +10.5 and $+13.3 \%$ and from Salar Ratones between +8.9 and $+9.8 \%$ o (Orberger et al. 2015). Brines from Salar Olaroz show $\delta^{7} \mathrm{Li}$ values from +5.9 to $+7.1 \%$ (surface) and +8.1 to $+10.2 \%$ o (depth of 150 to $450 \mathrm{~m}$ below surface from drill holes; Garcia et al. 2020). The study of the Salar de Hombre Muerto focussed on $\delta^{7} \mathrm{Li}$ values of rocks and water from feeders (range from +2.6 to $+9.4 \% o$ ) and assumes a $\delta^{7} \mathrm{Li}$ value of $+8.3 \%$ for the brine in the centre (Godfrey et al. 2013). These salars have large volcanic centres and/or large volume ignimbrite (Salar Olaroz) in their catchment areas as observable in satellite views (ESM2 Fig. A1 Google Earth link) or formed, as the deposits of the Salar de Atacama, by massive inflow of (ground)water from such catchments (Corenthal et al. 2016). Thermal water and groundwater reported from the Argentine Puna (Godfrey et al. 2013), from the Western Cordillera, and adjacent basins in the west (north of Salar de Atacama; Godfrey et al. 2019) show variable $\delta^{7} \mathrm{Li}$ values between -1 and $+13 \%$, with most samples plotting within the global hydrothermal field (Fig. 6a).

Our data labelled Li-Triangle, the Salar de Atacama, and ground- and thermal waters from the Western Cordillera show ${ }^{87} \mathrm{Sr} /{ }^{86} \mathrm{Sr}$ typical of regional andesite and comparable low $\delta^{7} \mathrm{Li}$, whereas brines from Salar Olaroz and feeders of Salar de Hombre Muerto show-at similar $\delta^{7} \mathrm{Li}-\mathrm{a}$ range of ${ }^{87} \mathrm{Sr} /{ }^{86} \mathrm{Sr}$ typical of large-volume ignimbrite and influence of radiogenic Pz-basement (Fig. 6b).

Active volcanism, arid climate, and internal draining since the Miocene are the background to weathering with generally restricted transport of solutes and solids in the Puna plateau (Alonso et al. 1991; reviews by Strecker et al. 2007; Vandervoort et al.1995). Catchment areas of the endorheic basins can be highly varied with respect to the prevailing surface geology caused by the rough morphology of the Puna. However, weathering conditions at the surface, humidity and temperature, should be similar to all salar basins (precipitation rates ranging from $25 \mathrm{~mm} /$ year for the Salar de Atacama to $150 \mathrm{~mm} /$ year for Salar de Uyuni, Houston et al. 2011 with no apparent correlation between annual precipitation rate and the Li isotope composition or assumed source rocks for lithium. The reason for the-compared with Pozuelos-low $\delta^{7} \mathrm{Li}$ values is likely the dominance of bulk dissolution (variable contribution from thermal waters) with a more restricted formation of secondary minerals in hydrothermal systems over weathering at the surface during Li release from the host rocks. This was recently demonstrated for ground waters that were (partially) released with high Li contents from geothermal fields in the Western Cordillera of the active arc and exported to foothill basins interacting with various rock reservoirs in the water table (Fig. 6; Godfrey et al. 2019). The variable ${ }^{87} \mathrm{Sr} /{ }^{86} \mathrm{Sr}$, i.e. the different host rocks of the $\mathrm{Li}$, shows no correlation with the $\delta^{7} \mathrm{Li}$.

\section{Insights from boron isotope compositions}

It has been shown, that the B isotope composition of fluids, borate minerals and salts from the Puna Plateau can be used to distinguish between the source rocks sampled 
by the mineralising fluids (Kasemann et al. 2004; Schmitt et al. 2002). The Palaeozoic basement was identified as the most significant boron source in the eastern Puna and Eastern Cordillera. Another important boron contribution comes from Cenozoic ignimbrites with dominance in the western Altiplano-Puna; Cenozoic andesites and Mesozoic limestones provide a third source. In contrast to lithium, the $\mathrm{B}$ isotope composition of the fluids appears to be not affected by secondary processes, i.e. secondary mineral precipitation, but rather directly reflects variations in the isotope composition of the source rocks (Kasemann et al. 2004; Schmitt et al. 2002). The B isotope composition of the Salar de Pozuelos surface brines ( -19.3 to $-1.8 \%$ ) encompasses nearly the whole spread of data measured for brines and thermal spring fluids across the eastern and western Puna (Fig. 4; -18.3 to $+5.7 \%$; Kasemann et al. 2004). The boron isotope composition for the salt on the surface $(-19.9$ to $-8.5 \%$ ) and in the core $(-18.1$ to $-14.1 \%$ ) is similar to the surface brines but more homogeneous, duplicating the values reported for halite in the Puna (Kasemann et al. 2004). The two borate (ulexite) samples show significantly different $\delta^{11} \mathrm{~B}$ values. The sample close to the Ordovician outcrop has a $\delta^{11} \mathrm{~B}$ value $(-17.5 \%$ o $)$ that corresponds to values observed in other salars and thermal springs of the eastern Puna (e.g. Salar de Pocitos $-16.7 \%$ o). In contrast, the ulexite value of $-6.7 \%$ is much more positive and corresponds to values observed so far only for the Neogene Loma Blanca borate deposit (Kasemann et al. 2004). The spread in the boron isotope data in the fluids and the salts, and the two contrasting values in the borates, suggests mixing of boron leached from the same two sources the lithium was leached from, Palaeozoic basement and the Cenozoic ignimbrites, and supports the results obtained from the strontium data. In contrast to the lithium, the main source for the boron are the basement rocks as seen for other salars in the eastern Puna. The offset between the present day B isotope composition of the spring water $(-9.1 \%$ ) and the travertine $(-23.5 \%$ ) points to a $\mathrm{pH}$ value of about 8.5 (assuming $20{ }^{\circ} \mathrm{C}$ fluid temperature and the $\delta^{11} \mathrm{~B}$-ocean $\mathrm{pH}$ relationship, Klochko et al. 2006); a value that falls well between the $\mathrm{pH}$ range of 7.9 and 8.7 reported for thermal springs in the eastern Puna (Kasemann et al. 2004).

The survey samples from the Li-Triangle cover a considerable range in their $\mathrm{B}$ isotope composition $(-6.5$ to $+16.7 \%$ ). In contrast to Pozuelos, most of the samples cluster approximately in the reported isotope range for thermal springs in the western Puna $(-6.5$ to $+7.8 \%$ o $)$ indicating B contributions mainly from the Cenozoic ignimbrites and andesites. Three samples from Salar Grande and Salar de Pedernales in Chile show $\delta^{11} \mathrm{~B}$ values that are significantly more positive $(+15.6$ to $+16.6 \%)$ than previously measured fluids in the Central Andes (e.g. Schmitt et al. 2002; Kasemann et al. 2004) suggesting the presence of marine limestones of Mesozoic age, spatially correlated with the salars.

\section{Conclusions}

The Li contents of the Salar de Pozuelos in the Puna Plateau is generated by chemical weathering in a cold and dry climate, and the formation of secondary minerals with the accompanied large Li isotope fractionation dominates the uniform and high $\delta^{7} \mathrm{Li}$ values of the deposit. The isotope composition does not record changes in the weathering regime over at least $100 \mathrm{ka}$ (or more) of deposition, despite various and well-documented pluvial-glacial periods in the Puna region. $\mathrm{Sr}$ and $\mathrm{Nd}$ isotope signatures of siliciclastic sediments from core DHH1 and Sr isotope signatures of all other salar basin and catchment area materials resemble those of large-volume ignimbrites as the dominant source rock for the Li with only minor additions from weathering of the prominent Ordovician rocks of the catchment area and hydrothermal leaching of the underlying $\mathrm{Pz}$ basement. The absence of volcanic edifices or extended volcanic deposits in the catchment area indicates the importance of air-fall or windblown material in the Cenozoic sediments of the catchment area and the salar basin. Compared with $\delta^{7} \mathrm{Li}$ signatures of other $\mathrm{Li}$ deposits and Li-bearing waters in the Puna and its western foothills, the Salar de Pozuelos represents the endmember of Li solubilisation from the host rock by near-surface chemical weathering. $\mathrm{Sr}$ and $\mathrm{Li}$ isotopes indicate that the degree of $\mathrm{Li}$ isotope fractionation is independent of the host rock, i.e. andesite, large-volume ignimbrite, and Palaeozoic basement as the principal contributors. Furthermore, $\delta^{7} \mathrm{Li}$ signatures of the evaporites give a clue on the mobilisation process of the $\mathrm{Li}$ between chemical weathering at the surface and processes including a higher proportion of bulk solution of the host rocks (bulk dissolution does not fractionate $\Delta^{7} \mathrm{Li}_{\text {residue-solution }}$ ), e.g. in geothermal waters.

Supplementary Information The online version contains supplementary material available at https://doi.org/10.1007/s00126-021-01062-3.

Acknowledgements AM would like to thank K. Hahne (HelmholtzZentrum Potsdam GFZ) for providing the salt and water samples from the Li-Triangle. The sampling took place during his fieldwork in the years 1997 to 2000 and was supported by the Collaborative Research Center SFB 267. SAK and RNA thank B. Heit for support in taking the core samples and supporting the sampling in Bolivia. RNA thanks 
C.M.R. Sorentino, R.M. Castañeda, C.I. Galli, R.V. Martinez and W. Rojas, for a long-term cooperation in Li studies of Puna salars. E. Schefuß (MARUM, Universität Bremen) is thanked for support with water isotope analyses, and thanks to the group Sediment Geochemistry (MARUM) for the analysis of the total element concentrations. The data reported in this paper are archived at the PANGAEA information system (Data Publisher for Earth \& Environmental Science; https:// www.pangaea.de/; https://doi.org/10.1594/PANGAEA.928849). We thank Horst Marschall and Gerhard Wörner for their reviews, which improved the focus of the manuscript, and Bernd Lehmann for the editorial handling.

Funding Open Access funding enabled and organized by Projekt DEAL.

Open Access This article is licensed under a Creative Commons Attribution 4.0 International License, which permits use, sharing, adaptation, distribution and reproduction in any medium or format, as long as you give appropriate credit to the original author(s) and the source, provide a link to the Creative Commons licence, and indicate if changes were made. The images or other third party material in this article are included in the article's Creative Commons licence, unless indicated otherwise in a credit line to the material. If material is not included in the article's Creative Commons licence and your intended use is not permitted by statutory regulation or exceeds the permitted use, you will need to obtain permission directly from the copyright holder. To view a copy of this licence, visit http://creativecommons.org/licenses/by/4.0/.

\section{References}

Alonso RN (1999) On the origin of La Puna Borates. Acta Geol Hisp 34:141-166

Alonso H, Risacher F (1996) Geoquimica del Salar de Atacama, parte 1: origen de los componentes y balance salino. Andean Geol 23:113-122

Alonso RN, Jordan TE, Tabbutt KT, Vandervoort DS (1991) Giant evaporite belts of the Neogene Central Andes. Geology 19:401-404

Aravena R, Suzuki O, Pefia H, Pollastri A, Fuenzalida H, Grilli A (1999) Isotopic composition and origin of the precipitation in Northern Chile. Appl Geochem 14:411-422

Blasco G, Zappettinni E, Hong F (1996) San Antonio de los Cobres. Programa Nacional de Cartas Geológicas de la República Argentina 1:250.000. Hoja Geológica 2566-I. Provincias de Jujuy y de Salta. Boletín 217. Buenos Aires, Servicio Geológico Minero Argentino. Instituto de Geología y Recursos Minerales

Bobst AL, Lowenstein TK, Jordan TE, Godfrey LV, Ku T-L, Luo S (2001) A 106 ka paleoclimate record from drill core of the Salar de Atacama, northern Chile. Palaeogeogr Palaeoclimatol Palaeoecol 173:21-43

Bohlin MS, Bickle MJ (2019) The reactive transport of Li as a monitor of weathering processes in kinetically limited weathering regimes. Earth Planet Sci Lett 511:233-243

Boschetti T, Cortecci G, Barbieri M, Mussi M (2007) New and past geochemical data on fresh to brine waters of the Salar de Atacama and Andean Altiplano, northern Chile. Geofluids $7: 33-50$
Brandmeier M, Wörner G (2016) Compositional variations of ignimbrite magmas in the Central Andes over the past $26 \mathrm{Ma}$ - a multivariate statistical perspective. Lithos 262:713-728

Chan LH, Edmond JM, Thompson G, Gillis K (1992) Lithium isotope composition of submarine basalts-Implications for the lithium cycle in the oceans. Earth Planet Sci Lett 108:151-160

Corenthal LG, Boutt DF, Hynek SA, Munk LA (2016) Regional groundwater flow and accumulation of a massive evaporite deposit at the margin of the Chilean Altiplano. Geophys Res Lett 43:8017-8025

Craig H (1961) Isotopic variations in meteoric waters. Science 133:1702-1703

Cullen JT, Hurwitz S, Barnes JD, Lassiter JC, Penniston-Dorland S, Kasemann SA, Thordsen JJ (2019) Temperature-dependent variations in mineralogy, major element chemistry and the stable isotopes of boron, lithium and chlorine resulting from hydration of rhyolite: constraints from hydrothermal experiments at 150 to $350{ }^{\circ} \mathrm{C}$ and $25 \mathrm{MPa}$. Geochim Cosmochim Acta 261:269-287

D'Arcy M, Schildgen T, Strecker MR, Wittmann H, Duesing W, Mey J, Tofelde S, Weissmann P, Alonso RN (2019) Timing of past glaciation at the Sierra de Aconquija, northwestern Argentina, and throughout the Central Andes. Quat Sci Rev 204:37-57

Egenhoff SO, Lucassen F (2003) Chemical and isotopic composition of lower to upper Ordovician sedimentary rocks (Central Andes/South Bolivia): implications for their source. J Geol 111:487-497

Ericksen GE, Salas R (1987) Geology and resources of Salars in the Central Andes. United States department of the Interior geological survey. Open-File Report 88-210

Eugster HP (1980) Geochemistry of evaporitic lacustrine deposits. Ann Rev Earth Planet Sci 8:35-63

Fiorella RP, Poulsen CJ, Pillco Zolá RS, Jefferya ML, Ehlers TA (2015) Modern and long-term evaporation of central Andes surface waters suggests paleo archives underestimate Neogene elevations. Earth Planet Sci Letts 432:59-72

Flesch GD, Anderson AR, Svec HJ (1973) A secondary isotopic standard for ${ }^{6} \mathrm{Li} /{ }^{7} \mathrm{Li}$ determinations. Int $\mathrm{J}$ Mass Spectrom $12: 265-272$

Flores LV, Lowenstein TK, Li J, Luo S, Ku TL, Alonso RN, Jordan TE (1997) Registro continuo del Pleistoceno Tardío basado en un testigo de halita del salar de Hombre Muerto, Argentina. VIII Congr Geol Chil I:332-336

Foster GL, Pogge Von Strandmann PAE, Rae JWB (2010) Boron and magnesium isotopic composition of seawater. Geochem Geophys Geosyst 11:1-10

Garcia MG, Borda LG, Godfrey LV, López Steinmetz RL, LosadaCalderon A (2020) Characterization of lithium cycling in the Salar De Olaroz, Central Andes, using a geochemical and isotopic approach. Chem Geol 531:119340

Garreaud RD, Vuille M, Compagnucci R, Marengo J (2009) Presentday South American climate. Palaeogeogr Palaeoclimatol Palaeoecol 281:180-195

Gehre M, Geilmann H, Richter J, Werner RA, Brand WA (2004) Continuous flow ${ }^{2} \mathrm{H} /{ }^{1} \mathrm{H}$ and ${ }^{18} \mathrm{O} /{ }^{16} \mathrm{O}$ analysis of water samples with dual inlet precision. Rapid Commun Mass Spectrom 18:2650-2660

Godfrey L, Álvarez-Amado F (2020) Volcanic and saline lithium inputs to the Salar de Atacama. Minerals 10. https://doi.org/10.3390/ $\min 10020201$

Godfrey LV, Jordan TE, Lowenstein TK, Alonso RL (2003) Stable isotope constraints on the transport of water to the Andes between 
$22^{\circ}$ and $26^{\circ} \mathrm{S}$ during the last glacial cycle. Palaeogeography, Palaeoclimatology, Palaeoecology 194(1-3):299-317

Godfrey LV, Chan L-H, Alonso RN, Lowenstein TK, McDonough WF, Houston J, Li J, Bobst A, Jordan TE (2013) The role of climate in the accumulation of lithium-rich brine in the Central Andes. Appl Geochem 38:92-102

Godfrey LV, Herrera C, Gamboa C, Mathur R (2019) Chemical and isotopic evolution of groundwater through the active Andean arc of Northern Chile. Chem Geol 518:32-44

Gonfiantini R, Tonarini S, Gröning M, Adorni-Braccesi A, Al-Ammar AS, Astner M, Bächler S, Barnes RM, Bassett RL, Cocherie A, Deyhle A, Dini A, Ferrara G, Gaillardet J, Grimm J, Guerrot C, Krähenbühl U, Layne G, Lemarchand D, Meixner A, Northington DJ, Pennisi M, Reitznerova E, Rodushkin I, Sugiura N, Surberg R, Tonn S, Wiedenbeck M, Wunderli S, Xiao Y, Zack T (2003) Intercomparison of boron isotope and concentration measurements. Part II: Evaluation of results. Geostand Geoanalytical Res 27:41-57

Goudie AS, Wells GL (1995) The nature, distribution and formation of pans in arid zones. Earth Sci Rev 38:1-69

Grosjean C, Miranda PH, Perrin M, Poggi P (2012) Assessment of world lithium resources and consequences of their geographic distribution on the expected development of the electric vehicle industry. Renew Sustain Energy Rev 16:1735-1744

Hains Engineering Company Limited (2018) Mineral Resource Estimate \& Technical Report on the salar de Pozuelos Project, Salta Province, Argentina. Report for LSC Lithium Corporation February 2018. https://www.lsclithium.com/properties/Pozue los/default.aspx (assessed 4/2020)

Hall K, Thorn CE, Matsuoka N, Prick A (2002) Weathering in cold regions: some thoughts and perspectives. Prog Phys Geogr 26:577-603

Hardie LA, Eugster HP (1970) The evolution of closed basin brines. Mineral Soc Amer Spec Pap 3:273-290

Hartley AJ, Chong G (2002) Late Pliocene age for the Atacama Desert: implications for the desertification of western South America. Geology 30:43-46

Haselton K, Hilley G, Strecker MR (2002) Average Pleistocene climatic patterns in the Southern Central Andes: controls on mountain glaciation and paleoclimate implications. J Geol 110:211-226

Henchiri S, Clergue C, Dellinger M, Gaillardet J, Louvat P, Bouchez J (2014) The influence of hydrothermal activity on the $\mathrm{Li}$ isotopic signature of rivers draining volcanic areas. Proc Earth Planet Sci 10:223-230

Hindshaw RS, Tosca R, Gout TL, Farnan I, Tosca NJ, Tipper ET (2019) Experimental constraints on Li isotope fractionation during clay formation. Geochim Cosmochim Acta 250:219-237

Höppner N, Lucassen F, Chiessi CM, Sawakuchi AO, Kasemann SA (2018) Holocene provenance shift of suspended particulate matter in the Amazon River basin. Q Sci Rev 190:66-80

Houston J, Butcher A, Ehren P, Evans K, Godfrey L (2011) The evaluation of brine prospects and the requirement for modifications to filing standards. Econ Geol 106:1225-1239

Hüpers A, Kasemann SA, Kopf AJ, Meixner A, Toki T, Shinjo R, Wheat CG, You C-F (2016) Fluid flow and water-rock interaction across the active Nankai Trough subduction zone forearc revealed by boron isotope geochemistry. Geochim Cosmochim Acta 193:100-118

Igarzábal AP (1991) Evaporitas cuaternarias de la Puna Argentina. En Pueyo J J (ed) Génesis de formaciones evaporíticas. Modelos andinos e ibéricos. Universidad de Barcelona, Estudios Generales, Publicación 2:333-374

Kasemann SA, Erzinger J, Franz G (2000) Boron recycling in the continental crust of the central Andes from the Palaeozoic to Mesozoic, NW Argentina. Contrib Mineral Petrol 140:328-343

Kasemann SA, Meixner A, Erzinger J, Viramonte JG, Alonso RN, Franz G (2004) Boron isotope composition of geothermal fluids and borate minerals from salar deposits (central Andes/NW Argentina). J S Am Earth Sci 16:685-697

Kay SM, Coira BL, Caffe PJ, Chen CH (2010) Regional chemical diversity, crustal and mantle sources and evolution of central Andean Puna plateau ignimbrites. J Vol Geoth Res 198:81-111

Kisakurek B, Widdowson M, James RH (2004) Behaviour of Li isotopes during continental weathering: the Bidar laterite profile, India. Chem Geol 212:27-44

Klochko K, Kaufman A, Yao W, Byrne R, Tossell J (2006) Experimental measurement of boron isotope fractionation in seawater. Earth Planet Sci Lett 248:276-285

López Steinmetz RL (2017) Lithium- and boron-bearing brines in the Central Andes: exploring hydrofacies on the eastern Puna plateau between $23^{\circ}$ and $23^{\circ} 30^{\prime} \mathrm{S}$. Miner Depos 52:35-50

López Steinmetz RL, Salvi S, Garcia MG, Peralta Arnold Y, Beziat D, Franco G, Constantini O, Cordoba F, Caffe PJ (2018) Northern Puna-scale survey of Li-brine deposits in the Andes of NW Argentina. J Geochem Explor 190:26-38

LSC Lithium Cooperation (2019) Preliminary Economic Assessment (PEA) - Pozuelos - Pastos Grandes Project NI 43-101 Technical Report Salta, Argentina January 2019. https://www.lsclithium. com/properties/Pozuelos/default.aspx (assessed 4/2020)

Lucassen F, Becchio R, Harmon R, Kasemann S, Franz G, Trumbull R, Wilke HG, Romer RL, Dulski P (2001) Composition and density model of the continental crust at an active continental margin - the Central Andes between $21^{\circ}$ and $27^{\circ} \mathrm{S}$. Tectonophysics 341:195-223

Mahlknecht J, Merchán D, Rosner M, Meixner A, Ledesma-Ruiza $\mathrm{R}$ (2017) Assessing seawater intrusion in an arid coastal aquifer under high anthropogenic influence using major constituents, $\mathrm{Sr}$ and B isotopes in groundwater. Sci Total Environ 587-588:282-295

Mandt KE, de Silva SL, Zimbelman JR, Crown DA (2008) Origin of the Medusae Fossae Formation, Mars: Insights from a synoptic approach. J Geophys Res 113:E12011

Marriott CS, Henderson GM, Crompton R, Staubwasser M, Shaw S (2004) Effect of mineralogy, salinity, and temperature on $\mathrm{Li} / \mathrm{Ca}$ and $\mathrm{Li}$ isotope composition of calcium carbonate. Chem Geol 212:5-15

Martínez VR, Alonso RN, Galli CI (2018) Historia evolutiva paleoambiental del depocentro del salar de Pozuelos (Puna Austral). Ser Correlación Geol 34:42-55. Tucumán

Martínez VR, Galli CI, Alonso RN (2020) Morfología de las costras evaporíticas del salar de Pozuelos, Puna Salteña. Rev Asoc Geol Argent 77:163-173

Meixner A, Sarchi C, Lucassen F, Becchio R, Caffe P, Lindsay J, Rosner M, Kasemann SA (2020) Lithium concentrations and isotope signatures of Palaeozoic basement rocks and Cenozoic volcanic rocks from the Central Andean arc and back-arc. Miner Depos 55:1071-1084

Meixner A, Alonso RN, Lucassen F, Korte L, Kasemann SA (2021) Stable and radiogenic isotope composition of salar deposits in the Central Andes. PANGAEA. 10.1594/PANGAEA.928849 
Millot R, Négrel P (2007) Multi-isotopic tracing $\left(\delta^{7} \mathrm{Li}, \delta^{11} \mathrm{~B},{ }^{87} \mathrm{Sr} /{ }^{86} \mathrm{Sr}\right)$ and chemical geothermometry: evidence from hydro-geothermal systems in France. Chem Geol 244:664-678

Millot R, Scaillet B, Sanjuan B (2010) Lithium isotopes in island arc geothermal systems: Guadeloupe, Martinique (French West Indies) and experimental approach. Geochim Cosmochim Acta 74:1852-1871

Mohr SH, Mudd GM, Giurco D (2012) Lithium resources and production: critical assessment and global projections. Minerals 2:65-84

Munk LA, Hynek SA, Bradley DC, Boutt D, Labay K, Jochens H (2016) Lithium brines: a global perspective. Rev Econ Geol $18: 339-365$

Munk LA, Boutt DF, Hynek SA, Moran BJ (2018) Hydrogeochemical fluxes and processes contributing to the formation of lithiumenriched brines in a hyper-arid continental basin. Chem Geol 493:37-57

Orberger B, Rojas W, Millot R, Flehoc C (2015) Stable isotopes (Li, $\mathrm{O}, \mathrm{H})$ combined with brine chemistry: powerful tracers for $\mathrm{Li}$ origins in Salar deposits from the Puna region, Argentina. Proc Earth Planet Sci 13:307-311

Penniston-Dorland S, Liu XM, Rudnick RL (2017) Lithium Isotope Geochemistry. Rev Mineral Geochem 82:165-217

Pistiner JS, Henderson GM (2003) Lithium-isotope fractionation during continental weathering processes. Earth Planet Sci Letts 214:327-339

Placzek C, Quade J, Betancourt JL, Patchett PJ, Rech JA, Latorre C, Matmon A, Holmgren C, English NB (2009) Climate in the dry Central Andes over geologic, millennial and interannual timescales. Ann Missouri Bot Gard 96:386-397

Pogge von Strandmann PAE, Burton KW, Opfergelt S, Eiríksdóttir ES, Murphy MJ, Einarssonf A, Gislason SR (2016) The effect of hydrothermal spring weathering processes and primary productivity on lithium isotopes: Lake Myvatn, Iceland. Chem Geol 445:4-13

Prospero JM, Ginoux P, Torres O, Nicholson SE, Gill TE (2002) Environmental characterization of global sources of atmospheric soil dust identified with the NIMBUS 7 Total Ozone Mapping Spectrometer (TOMS) absorbing aerosol product. Rev Geophys 40:1002

Quade J, Dettinger MP, Carrapa B, DeCelles P, Murray KE, Huntington KW, Cartwright A, Canavan RR, Gehrels G, Clementz M (2015) The growth of the central Andes, $22^{\circ} \mathrm{S}-26^{\circ} \mathrm{S}$. In DeCelles PG, Ducea MN, Carrapa B, Kapp PA eds Geodynamics of a Cordilleran Orogenic System: The Central Andes of Argentina and Northern Chile. Geol Soc Am Mem 212. https://doi.org/10.1130/ 2015.1212(15)

Ramírez C, Gardeweg M (1982) Geología de la hoja Toconao: Región de Antofagasta, escala 1:250.000, Santiago, Carta Geológica de Chile, Serie Geología Básica 54. Santiago: Instituto de Investigaciones Geológicas, p. 122

Reutter K-J, Munier K (2006) Digital Geological map of the Central Andes. In: Oncken O, Chong G, Franz G, Giese P, Götze H-J, Ramos VA, Strecker MR, Wigger P (eds.) The Andes. SpringerVerlag Berlin Heidelberg

Reutter K-J, Döbel R, Bogdanic T, Kley J (1994) Geological Map of the Central Andes between $20^{\circ} \mathrm{S}$ and $26^{\circ} \mathrm{S}, 1: 1.000 .000$. In: Reutter K-J, Scheuber E, Wigger P (eds.): Tectonics of the Southern Central Andes. Berlin, Heidelberg, New York: Springer Verlag

Risacher F, Fritz B (2009) Origin of salts and brine evolution of Bolivian and Chilean salars. Aquat Geochem 15:123-157
Risacher F, Alonso H, Salazar C (2003) The origin of brines and salts in Chilean salars: a hydrochemical review. Earth Sci Rev 63:249-293

Rissmann C, Leybourne M, Benn C, Christenson B (2015) The origin of solutes within the groundwaters of a high Andean aquifer. Chem Geol 396:164-181

Romer RL, Meixner A, Hahne K (2014) Lithium and boron isotopic composition of sedimentary rocks - the role of source history and depositional environment: a 250 Ma record from the Cadomian orogeny to the Variscan orogeny. Gondwana Res 26:1093-1110

Ruggieria F, Saavedra J, Fernandez-Turiela JL, Gimenoc D, GarciaValles M (2010) Environmental geochemistry of ancient volcanic ashes. J Hazard Mater 183:353-365

Sauzéat L, Rudnick RL, Chauvel C, Garcon M, Tang M (2015) New perspectives on the $\mathrm{Li}$ isotopic composition of the upper continental crust and its weathering signature. Earth Planet Sci Letts 428:181-192

Schildgen TF, Robinson RAJ, Savi S, Phillips WM, Spencer JQG, Bookhagen B, Scherler D, Tofelde S, Alonso RN, Kubik PW, Binnie SA, Strecker MR (2016) Landscape response to late Pleistocene climate change in NW Argentina: Sediment flux modulated by basin geometry and connectivity. J Geophys Res Earth Surf 121:392-414

Schmitt AK, Kasemann S, Meixner A, Rhede D (2002) Boron in central Andean ignimbrites: implications for crustal boron cycles in an active continental margin. Chem Geol 183:333-347

Schnurr W, Risse A, Trumbull R, Munier K (2006) Digital geological map of the southern and central Puna Plateau, NW Argentina. In: Oncken O, Chong G, Franz G, Giese P, Götze H, Ramos VA, Strecker MR, Wigger P (eds) The Andes: Active Subduction Orogeny: Frontiers in Earth Sciences. Berlin-Heidelberg: Springer-Verlag, pp 563-564

Schnurr W, Trumbull RB, Clavero J, Hahne K, Siebel W, Gardeweg M (2007) Twenty-five million years of silicic volcanism in the southern central volcanic zone of the Andes: geochemistry and magma genesis of ignimbrites from 25 to $27^{\circ} \mathrm{S}, 67$ to $72^{\circ} \mathrm{W}$. J Volc Geoth Res 166:17-46

Stoertz GE, Ericksen GE (1974) Geology of salars in Northern Chile. USGS Prof Pap 811:1-65

Strecker MR, Alonso RN, Bookhagen B, Carrapa B, Hilley GE, Sobel ER, Trauth MH (2007) Tectonics and climate of the southern central Andes. Annu Rev Earth Pl Sci 35:747-787

Teng FZ, McDonough WF, Rudnick RL, Dalpé C, Tomascak PB, Chappell BW, Gao S (2004) Lithium isotopic composition and concentration of the upper continental crust. Geochim Cosmochim Acta 68:4167-4178

Tomascak PB, Magna T, Dohmen R (2016) Li partitioning, diffusion and associated isotopic fractionation: Theoretical and experimental insights. In: Advances in Lithium Isotope Geochemistry. Advances in Isotope Geochemistry Springer. Cham: Springer, pp. $7-118$

Trumbull RB, Wittenbrink R, Hahne K, Emmermann R, Büsch W, Gerstenberger H, Siebel W (1999) Evidence for Late Miocene to Recent contamination of arc andesites by crustal melts in the Chilean Andes (25-26S) and its geodynamic implications. J S Am Earth Sci 12:135-155

U.S. Geological Survey (2020) Mineral commodity summaries 2020: U.S. Geological Survey. https://doi.org/10.3133/ $\operatorname{mcs} 2020$ 
Vandervoort DS, Jordan TE, Zeitler PK, Alonso RN (1995) Chronology of internal drainage development and uplift, southern Puna plateau; Argentine central Andes. Geology 23:145-148

Vigier N, Decarreau A, Millot R, Carignan J, Petit S, France-Lanord C (2008) Quantifying Li isotope fractionation during smectite formation and implications for the Li cycle. Geochim Cosmochim Acta 72:780-792

Vinante D, Alonso RN (2006) Evapofacies del Salar Hombre Muerto, Puna Argentina: distribución y genesis. Rev Asoc Geol Argentina 61:286-297

Warren JK (2010) Evaporites through time: Tectonic, climatic and eustatic controls in marine and nonmarine deposits. Earth Sci Rev 98:217-268

Wasserburg GJ, DePaolo DJ (1979) Models of earth structure inferred from neodymium and strontium isotopic abundances. Proc Natl Acad Sci 76:3594-3598
Weynell M, Wiechert U, Schuessler JA (2017) Lithium isotopes and implications on chemical weathering in the catchment of Lake Donggi Cona, northeastern Tibetan Plateau. Geochim Cosmochim Acta 213:155-177

Wimpenny J, Gislason SR, James RH, Gannoun A, Pogge Von Strandmann PAE, Burton KW (2010) The behaviour of Li and Mg isotopes during primary phase dissolution and secondary mineral formation in basalt. Geochim Cosmochim Acta 74:5259-5279

Wörner G, Mamani M, Blum-Oeste M (2018) Magmatism in the Central Andes. Elements 14:237-244

Publisher's note Springer Nature remains neutral with regard to jurisdictional claims in published maps and institutional affiliations. 